\title{
Bokmål, nynorsk eller språklig nøytral?
}

\section{En studie av målvedtak og målformpraksis i kommunene}

Av Tom Flaten og Magnhild Vollan

\begin{abstract}
Artikkelen presenterer en empirisk studie av språklig praksis knytta til målform på 277 kommuners nettsider. Materialet er todelt. Del 1, som blei samla inn høsten 2019, omfatter 271 kommuner som enten har målvedtak om nynorsk eller er språklig nøytrale. Del 2 blei samla inn våren 2020 og omfatter seks nye, sammenslåtte kommuner som består av tidligere kommuner med ulike målvedtak, der minst én hadde vedtak om nynorsk. Studien søker svar på denne problemstillinga: I hvilken grad er det samsvar mellom kommunenes målvedtak og kommunenes målformpraksis på nettsidene? I artikkelen dokumenteres manglende samsvar mellom målvedtak og målformpraksis i mange kommuner og konsekvenser av kommunesammenslåing. Et hovedfunn er at språklig nøytrale kommuner i all hovedsak fungerer som bokmålskommuner på sine nettsider. Vi drøfter på bakgrunn av dette språknøytralitet ut fra språkrettighetsteori, og særlig hva som ligger i begrepet språklig nøytral kommune.
\end{abstract}

\section{Innledning}

Norge blir ofte trukket fram som et foregangsland når det gjelder talespråklig toleranse og skriftspråklig variasjon (Rambø 2014: 50). Siden vi ikke har noe norsk standardtalemål, står vi fritt til å bruke dialekt i enhver sammenheng, og i skriftlig norsk forholder vi oss til to likestilte målformer som begge har stor valgfrihet i rettskrivinga. Den norske språksituasjonen gir altså språkbrukerne valgmuligheter og individuell frihet i tale og skrift, samtidig innebærer denne situasjonen lovregulering av språklig praksis på ulike samfunnsområder, blant anna i kommunene. 
Lov om målbruk i offentleg teneste [mållova] (1980) understreker i $\$ 1$ at bokmål og nynorsk er likeverdige målformer som «skal vere jamstelte skriftspråk i alle organ for stat, fylkeskommune og kommune». I tråd med prinsippet om likestilling av de to målformene, som Stortinget vedtok allerede i 1885 , beskriver mållova i detalj den særlige plikten statstjenesten har til å bruke både nynorsk og bokmål. I lovas $₫ 5$ beskrives reglene for åssen fylker og kommuner kan fatte målvedtak om nynorsk eller bokmål i henholdsvis fylkesting og kommunestyre. På kommunenivå kan en også vedta bestemmelser knytta til administrasjonsspråk og målbruksplan, uten at mållova pålegger dette. Språkbruk innenfor offentlig forvaltning er slik sett delvis lovregulert.

Denne artikkelen presenterer en studie av målvedtak og målformpraksis i kommunene. Det empiriske grunnlaget for studien er ei kartlegging av bruken av nynorsk og bokmål på utvalgte kommuners nettsider. Materialet er todelt. Unders $\varnothing$ kelsens del 1 er avgrensa til de kommunene som enten hadde valgt nynorsk som sin målform eller som var språklig nøytrale, ${ }^{1}$ og presenterer disse kommunenes målformpraksis slik den var før 1. januar 2020. ${ }^{2}$ Unders $\varnothing$ kelsens del 2 er avgrensa til seks sammenslåtte kommuner ${ }^{3}$ som består av tidligere kommuner med ulike målvedtak, der minst én hadde vedtak om nynorsk. Disse seks nye kommunene utgjør samtlige kommuner med denne bakgrunnen, og vi presenterer deres målformpraksis våren 2020. Materialet er henta fra kommunale nettsider siden disse utgjør ei viktig kontaktflate i våre dager. Hva kommunene gjør der, reint språklig, kan oppfattes som viktige språkpolitiske signal. Er det for eksempel slik at kommuner med målvedtak om nynorsk bruker nynorsk på nettsidene sine, mens språknøytrale kommuner bruker både nynorsk og bokmål? Mange har nok en antakelse om at språklig nøytrale kommuner bruker mest bokmål. Det har for eksempel Teigen (2001: 144) når han påstår om språklig nøytrale kommuner at «desse kommunane har alltid i hovudsak vore bokmålskommunar».

1. nøytral a1 (fra latin av neuter 'ingen av de to'; jamfør nøytrum) 1 som ikke tar parti, upartisk [...] (Bokmålsordboka 2020).

2. Kommunereformen gjorde at 119 av landets kommuner blei til 47 nye kommuner fra 1.1.2020 (Regjeringen, 202O).

3. De seks nye kommunene består av 18 tidligere kommuner (se tabell 2). 17 av disse inngår i del 1 av materialet siden de hadde målvedtak om nynorsk eller var språklig nøytrale før sammenslåinga. 
Vi drøfter resultata av kartlegginga i lys av målvedtak og setter dem inn i debatten om de to målformene i kommunal forvaltning. På denne måten s $\varnothing$ ker vi svar på f $\varnothing$ lgende problemstilling: I hvilken grad er det samsvarmellom kommunenes målvedtak og kommunenes målformpraksispå nettsidene? Gjennom kartlegginga av de seks nye kommunene i del 2 får vi dessuten mulighet til å studere utviklinga av målvedtak og målformpraksis kort tid etter kommunereformen. Avslutningsvis drøfter vi språknøytralitet ut fra språkrettighetsteori, og særlig hva som ligger i begrepet språklig nøytral kommune.

Det er flere grunner til at de kommunale nettsidene utgjør et interessant studieobjekt. For det første har alle kommuner egne nettsider (Grønntun 2010: 21). I stortingsvedtaket fra 2014 om universell utforming av nye nettsider retta mot allmennheten kan vi lese at "kommunene, fylkeskommunene og staten som hovedregel skal kommunisere digitalt med innbyggere og næringsliv» (Regjeringen 2014). Også på kommunenivå ses nettsidene som kommunenes «viktigste digitale portal for innbyggerne» (Indre Fosen kommune 2019). Det er betydelig interesse for kommunale nettsider, både på et forvaltningsnivå og forskningsnivå. KS har nylig laga en ny navigasjonsstruktur for kommunale nettsider som skal være godt tilpassa sektoren. Ifølge KS vil den nye strukturen sammen med prosjekter som «Klart språk» og kravet om universell utforming bidra til å sette brukeren i sentrum og å effektivisere kommunikasjonen og styrke tilliten til det offentlige (KS 2019: 2). Når det gjelder faglig eller vitenskapelig arbeid med kommunale nettsider som studieobjekt, finner vi arbeider innen forvaltningsinformatikk (Grønntun 2010) og samfunnsfag (Solvoll, Buhmann \& Bang 2018).

I en spørreunders $\varnothing$ kelse om målbruk i nynorskkommuner og utvalgte nøytrale kommuner inngår to spørsmål om målformbruk på de kommunale nettsidene (Språkrådet, Landssamanslutninga av nynorskkommunar $\&$ Nynorsk kultursentrum 2011). Denne unders $\varnothing$ kelsen bygger på sjølrapportering fra kommunene. For $\emptyset$ vrig er det ikke gjort mer omfattende studier knytta til målformpraksis på kommunale nettsider. Grunnen kan være at slike nettsider er en relativt ny kommunikasjonsplattform. Etter vårt syn er denne sentrale arenaen for kommunal målformpraksis moden for ei grundig kartlegging og drøfting.

Vi bygger på tidligere forskning og teori knytta til målform og språklig nøytralitet (Grønnvik 1987; Bjørhusdal 2014). Den særegne norske skriftspråkshistorien er grundig unders $\varnothing \mathrm{kt}$ av flere, i denne sammenheng 
også det kommunale perspektivet på målform (Lilleholt og Kihl 2014). I drøftinga får særlig begrepet språklig nøytral kommune en viktig plass, og der brukes innsiktene fra Bjørhusdal (2014) om språknøytralitet. Hennes fornorsking av to relevante og viktige begreper fra språkrettighetsteori, «velmeinande likesæle» og «raus rettferd» (Bjørhusdal 2014: 69f.), blir sentrale for vår drøfting. I artikkelen vektlegger vi presentasjonen av empiriske funn som vi deretter drøfter i lys av teoretiske perspektiver.

\section{Bakgrunn}

Nedenfor gis først en presentasjon av en del begreper som er sentrale i denne studien. Deretter gjør vi greie for teoretiske perspektiver på språklig nøytralitet, faglig arbeid om målformene og nyere språkpolitiske dokumenter. Gjennom dette belyser vi noen teoretiske, forskningsmessige og samfunnsmessige forhold ved temaet. Denne bakgrunnen trekker vi seinere inn i drøftinga av de empiriske funna.

\subsection{Sentrale begreper}

Kommunenes målformvalg eller målvedtak er avgjørende for vårt utvalg av kommuner. Det er mållova (1980) som legger grunnlaget for valg og inndeling av kommunene i materialet. I \5 i mållova står det at kommunestyret kan vedta hvilken målform en $\varnothing$ nsker å få skriv fra staten på. Dette blir kalt kommunalt tjenestemål. Eventuelt kan det vedtas at kommunen skal være språklig nøytral, noe som betyr at en ikke krever én bestemt målform. Videre står det at en kommune som ikke gjør vedtak om målform, skal regnes som språklig nøytral. Vårt utvalg av kommuner er basert på oversikten over kommunenes målvedtak gjengitt $\mathrm{i}$ «Forskrift om målvedtak i kommunar og fylkeskommunar» høsten 2019 og våren 2020.

Figur 1 viser oversikt over fordelinga av målvedtak i kommunene fra 1933 til 2020. Med mållova av 1930 blei det innført at kommunene kunne gjøre målvedtak (Grønvik 1987: 40), og dette blei videreført i mållova av 1980. 


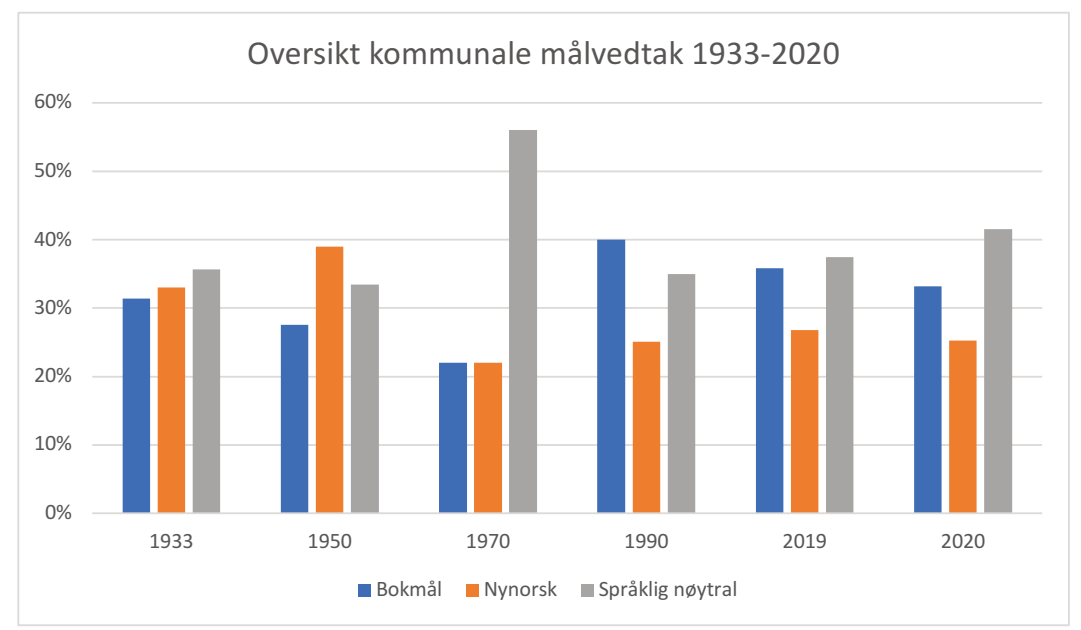

Figur 1: Oversikt over målformvedtak i kommunene fra 1933 til 2020 i prosent. ${ }^{4}$

Figur 1 viser ei jevn fordeling mellom de tre alternativa i 1933. Andelen kommuner med nynorsk $\varnothing$ kte fram til 1950, mens andelen bokmålskommuner falt. Etter de mange kommunesammenslåingene på 1960-tallet

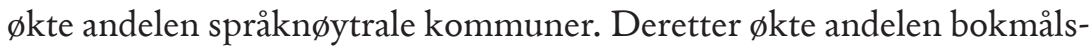
kommuner fram mot 1990. Etter kommunereformen i 2020 har andelen språklig nøytrale kommuner $\varnothing \mathrm{kt}$ igjen, men ikke i like stor grad som etter kommunesammenslåingene på 1960-tallet.

Kommunene kan i tillegg fatte egne vedtak om administrasjonsspråket. Administrasjonsspråket er målformen kommunen og dens ansatte skal benytte i sitt arbeid. Gramstad \& Lilleholt (1983: 42) understreker at «[d]et har vore vanleg å tolke vedtak om å krevje ei viss målform slik at vedtaket også gjeld tenestemålet ${ }^{5}$ for dei kommunalt tilsette», men at det kan gjøres særskilt vedtak om dette. Tvitekkja (2010: 24) peker på at administrasjonsspråket i all hovedsak er det samme som i kommunenes målvedtak: «Det er ofte samsvar mellom målforma i målvedtaket, som rettar seg «oppover» mot statsadministrasjonen, og det kommunale administrasjonsspråket som rettar seg «utover» - til innbyggjarane i kom-

4. Tall for 1933 og 1950 fra Vogt-komitéen (1966: 6). Tall for 1970 og 1990 fra Grepstad (2005: 437-438). Tall for 2019 og 2020 fra forskrift om målvedtak på lovdata.no.

5. Her brukes tjenestemål om målformen de kommunalt ansatte skal bruke, altså administrasjonsspråk. 
munen». Det finnes ingen fullstendig oversikt over administrasjonsspråk i kommunene, og Grepstad (2005: 429) påstår sågar at «nokre kommunar veit heller ikkje sjølve kva vedtak som finst om dette». I en undersøkelse om målbruk i nynorskkommuner og utvalgte nøytrale kommuner (Språkrådet et al. 2011: 6f.) svarer 21 \% at målvedtaket også gjelder for administrasjonsspråket. $63 \%$ har vedtatt at administrasjonen skal bruke nynorsk, $11 \%$ har vedtatt at administrasjonen kan velge, mens $6 \%$ svarer at kommunen ikke har fatta vedtak om administrasjonsmålet.

Kommunene kan også lage egne målbruksplaner, for eksempel kan en språknøytral kommune lage en plan om å likestille nynorsk og bokmål, eventuelt bestemme hvilke saksområder som skal ha dokumenter på den ene målformen og hvilke som skal ha på den andre. Lilleholt og Kihl (2014: 34) peker på målbruksplaner som et særlig virkemiddel for å ivareta nynorsken i språknøytrale kommuner. De understreker at planene må ha «klare retningsliner for språkbruk og språkrøkt i kommunen». Vi har ikke tatt hensyn til målbruksplaner i denne studien, men vi registrerer at slike planer er blitt mer utbredt etter kommunereformen i 2020.

Når statlige organ skal sende ut skriv til flere kommuner i et avgrensa område, for eksempel til alle kommunene i et fylke, skal de bruke flertallsmålformen. Flertallsmålformen er i mållova $\$ 7$ definert som den målformen som flertallet av kommunene i området har vedtatt. Tvitekkja (2010: 25) peker på at regionale statsorgan, som fylkesmennene (nå: statsforvalterne), kan ha tjenestemål, og dette skal være flertallsmålformen i det aktuelle fylket.

Lov om grunnskolen og den vidaregåande opplæringa [opplæringslova] (1998) gir i $\$ 2-5$ kommunene ansvar for å gi forskrift om hvilken målform som skal være hovedmål i de enkelte skolene. Hovedmålet skal brukes i skriftlig opplæring og i skriftlig arbeid, mens elevene skal ha opplæring i begge målformer de to siste åra i grunnskolen. I samme paragraf beskrives kommunenes plikter i møte med rettigheter elevene og foreldrene har når det gjelder målformene i grunnskolen, blant anna at det skal holdes rådgivende avstemning i forbindelse med spørsmål om skifte av skolens hovedmål.

I den faglige omtalen av målformenes posisjon i ulike landsdeler brukes ofte begreper som kjerneområder og grenseområder eller randsoner. Lunde (2O2O: 119f.) sier at felles for de kommunene som gjerne blir kalt kjerneområdet for nynorsk, er at nynorsk er den samfunnsbærende målformen, både tradisjonelt og i dag. Også i de kommunene som kalles ny- 
norskens randsoner, har nynorsk tradisjonelt vært den samfunnsbærende målformen, men den er nå i tilbakegang. Randsonene kan også være kommuner som grenser til bokmålsdominerte kommuner. Disse begrepene er omdiskutert, og i praksis er de først og fremst basert på opplysninger om skolemål. Med henvisning til talla fra Grunnskolens Informasjonssystem (GSI) om elevenes opplæringsmålform (se tabell 1) utgjør deler av følgende fylker kjerneområdet for nynorsk: Sogn og Fjordane, Møre og Romsdal og Hordaland. Her skiller Sogn og Fjordane seg særlig ut som et sammenhengende kjerneområde for nynorsk. For Møre og Romsdal er det Sunnmøre som er del av nynorskens kjerneområde, med unntak av byen Ålesund. I Hordaland er det et tydelig skille mellom Bergens-området, som er dominert av bokmål, og de $\varnothing$ vrige delene av fylket der nynorsk står sterkt. Nynorsk er også noe utbredt som skolemål i Rogaland, Opppland og Telemark. I grenseområdene eller randsonene finner en kommuner med både bokmåls- og nynorskskoler (Nordal 2011: 114).

Tabell I (under): Grunnskoleelevenes opplaringsmålform i prosent, skoleåret 201920. Tall fra GSI. ${ }^{6}$ Elever med samisk som morsmål er ikke tatt med.

\begin{tabular}{|l|c|c|l|c|c|c|}
\hline Fylke & Bokmål & Nynorsk & Vest-Agder & 97 & 3 \\
\hline Østfold & 100 & 0 & Rogaland & 78 & 22 \\
\hline Akershus & 100 & 0 & Hordaland & 62 & 38 \\
\hline Oslo & 100 & 0 & Sogn og Fjordane & 2 & 98 \\
\hline Hedmark & 100 & 0 & Møre og Romsdal & 51 & 49 \\
\hline Oppland & 84 & 16 & Trøndelag & 100 & 0 \\
\hline Buskerud & 98 & 2 & Nordland & 100 & 0 \\
\hline Vestfold & 100 & 0 & Troms & 100 & 0 \\
\hline Telemark & 91 & 9 & Finnmark & 100 & 0 \\
\hline Aust-Agder & 95 & 5 & Norge & $\mathbf{8 8}$ & $\mathbf{1 2}$ \\
\hline
\end{tabular}

\subsection{Teoretiske perspektiver på språklig nøytralitet}

Flere tar et språkpolitisk perspektiv når de undersøker og drøfter forholdet mellom bokmål og nynorsk. Thingnes (2020) unders $\varnothing$ ker åssen avgjørelsen om å ha nynorsk som hovedspråk ved Høgskulen på Vestlandet blei begrunna og konkretisert i institusjonens arbeid med språkpolitiske retningslinjer. Hun drøfter hva som skjer i det språkpolitiske feltet mellom ideal og realitet. Videre viser hun åssen nynorsk er del av

6. Prosenttalla er avrunda etter vanlige regler. I tabellen følges fylkesinndelinga som gjaldt ved skolestart 2019 . 
en minoritetsspråksdiskurs der språkvalg stadig må forklares og begrunnes.

Nordal (2017) tar utgangspunkt i at alle språk har en kulturell egenverdi og at språkpolitikken derfor må utformes slik at staten tar vare på denne verdien, sjøl om det fører til favorisering av små og utsatte språkgrupper. Videre sier hun at «[s]pråkpolitikken vil vere ulik om ein vil sikre språket sin eksistens eller om ein har språkleg nøytralitet som mål» (Nordal 2017: 239). Hun hevder at statlig nøytralitet ikke er nok til å opprettholde mindretallsspråket nynorsk, verken i opplæringa eller i det norske samfunnet ellers. Bjørhusdal (2015) analyserer forvaltninga av nynorsk og bokmål i skoleverket. Hun peker også på at språkpolitikken på dette området har hatt som mål å sikre nøytralitet, men at det kan ha vært til hinder for mindretallet, altså nynorskelevene.

I en annen artikkel presenterer og drøfter Bjørhusdal (2016) norsk språkforvaltning sett i lys av en velferdsteoretisk kontekst. Det betyr at Bjørhusdal ser på språket som en del av velferdsmodellen, for eksempel hvilke offentlige reguleringer gjennom velferdsstaten som tar vare på folks språklige rettigheter. I denne sammenheng er det særlig drøftinga av begrepet språknøytralitet som er interessant. Her sier Bjørhusdal (2016: 107) at «statleg språknøytralitet rett og slett ikkje er mogleg». Det begrunnes med at staten alltid vil være en språkinstitusjon fordi den må uttrykke seg gjennom språk. Dette er et teoretisk utgangspunkt som Bjørhusdal (2014) også har i si doktorgradsavhandling. Der løfter hun fram forholdet mellom bokmål og nynorsk i et språkpolitisk perspektiv. Hun belyser den historiske utviklinga og setter den norske språksituasjonen inn i en teoretisk sammenheng, med vekt på teori knytta til språkrettigheter. Innen språkrettighetsteori er begrepet språknøytralitet et sentralt, men dels omstridt begrep.

Bjørhusdal (2014: 68) skiller mellom nøytralitetspolitikk som enten st $\varnothing t t e r$ positive eller negative rettigheter. Positive rettigheter kobler hun til begrepet «evenhandedness» av Carens (2000: 77-78). Bjørhusdal (ibid.: 69) kaller det «raus rettferd», og beskriver det som en nøytralitet der staten tilrettelegger aktivt for alle språkgrupper. Negative rettigheter kobles til Kymlickas begrep «benign neglect», kalt «velmeinande likesæle» av Bjørhusdal. Patten og Kymlicka (2003: 32) sier at minst mulig statlig involvering, også i språkspørsmål, vil være et mål. Imidlertid sier de at sjøl om staten kan holde seg unna språkbruk i den private sfære, er det umulig for staten på andre områder: «there is no way for it [staten] 
to avoid taking a stand on a whole series of other language policies» (ibid.). Det gjelder for eksempel offentlige tjenester og offentlig skole. Bjørhusdal (2014: 71) oppsummerer med at «[e]in verdin $\varnothing y$ tral stat bygd på negative rettar kan ikkje aktivt tilretteleggje for eit mindretalsspråk».

Bjørhusdal (2014: 459) bygger altså på en modell for språklig nøytralitet som tar utgangspunkt i språkpolitikkens «(eventuelle) prosedurale argumentasjon og spør om denne stør positive eller negative rettar». Bjørhusdal sier videre at hennes materiale viser «at norsk språkpolitikk i heile den granska perioden gjev nynorskbrukarar positive rettar» (ibid.). Bjørhusdal granska språksituasjonen mellom 1885 og 2005, og hun konkluderer med at nøytralitetspolitikk prega perioden fram til 1980, særlig raus rettferd (ibid.: 486). Språksikring blir et viktigere begrep i den nyere delen av historien, og språksikringspolitikk er politikk som skal sikre mindretallets språk, og legitimeres blant anna gjennom egenverdien språket har for brukerne (ibid.: 78). I perioden etter 1980 meiner Bjørhusdal at politikken vakler mellom nøytralitet og språksikring. At en har gått bort fra samnorsktanken, fører til at de to skriftspråka får en st $\varnothing r r e ~ e g e n-$ verdi som sjølstendige skriftspråk.

\subsection{Faglige arbeider om målform}

Heilt siden mållova i 1930 ga åpning for språklig nøytrale kommuner, meiner Grønvik (1987: 234) at begrepet har vært utfordrende fordi det var uklart «kva som i røynda låg attom nemninga nøytral». Da spørsmålet om statlig tjenestemål blei reist på 1920-tallet, ville Noregs Mållag at kommunene skulle kreve statlige skriv på nynorsk, og seinere gjorde Riksmålsforbundet det samme for bokmål. Det førte ifølge Grønvik til «det tredje standpunktet», altså at noen kommuner ikke tok et standpunkt, eller at noen kommuner faktisk gjorde «vedtak om å krevja tilfang på båe målformer frå staten» (ibid.). Grønvik viser videre at flere av disse kommunene grunnga dette med at «dei $\varnothing$ nskte å vera nøytrale i høve til målstriden» (ibid.: 235). Mållova omtalte ikke de nøytrale kommunene, og de blei også i liten grad behandla i forskriftene som fulgte de neste åra. En kunne tenke seg at språknøytrale kommuner skulle få statlige skriv på begge målformer, men regjeringa valgte ei tilnærming som tolka de språklig nøytrale kommunene som «likesæl med målform» (ibid.: 242). Dermed kunne statens organ fritt velge målform i kommunikasjon med disse kommunene. 
Målformpraksis i språklig nøytrale kommuner er i liten grad undersøkt tidligere. Som nevnt ovenfor meiner Teigen (2001: 144) at språklig nøytrale kommuner i all hovedsak er bokmålskommuner. Det virker mest basert på en allmenn opplevelse, men kan naturligvis også begrunnes ut fra opplæringsmålform i landets kommuner som tabell 1 gir en oversikt over. Vikør (2011: 87) diskuterer også begrepet språklig nøytral kommune, og hans antakelse er: "Omgrepet "nøytral" i denne samanhengen betyr nok i realiteten "bokmål", i alle fall i større byar, men i mindre kommunar der nynorsk har ei viss stilling blant folk, kan det nok tenkjast at "nøytraliteten" er meir reell, altså opnar for ein viss bruk av begge målformene». Vi ser at Vik $\varnothing$ r skiller mellom ulike typer kommuner, men han gir ingen entydig beskrivelse av språklig nøytral kommune.

I en spørreunders $\varnothing$ kelse (Språkrådet et al. 2011) om målbruken i de 114 nynorskkommunene og 11 nøytrale kommuner der nynorsk tradisjonelt står sterkt blant innbyggerne, blei det stilt spørsmål blant anna om målform i skriv fra staten, om administrasjonsspråket i kommunene og om målformbruk i interkommunale og kommunale foretak. Den totale svarprosenten er $72 \%$, men varierer noe fra spørsmål til spørsmål. Trass $\mathrm{i}$ at unders $\varnothing$ kelsen kun bygger på sjølrapportering fra kommunene, har den noen interessante poeng, og vi trekker fram to som er relevante her. Det første er at 13 kommuner med målvedtak om nynorsk svarte at de var språklig nøytrale, noe som betyr «at ein del av (dei tilsette i) kommunane ikkje er klar over at nynorsk er gjeldande målvedtak, eller over kva eit målvedtak inneber» (Språkrådet et al. 2011: 2). At situasjonen er slik7, kan skape utfordringer i målformpraksisen. Det andre poenget gjelder svara på de to spørsmåla som handler om målformbruk på de kommunale nettsidene. Ifølge talla som gjelder for nynorskkommunene, bruker 92 \% nynorsk, mens 8 \% bruker både nynorsk og bokmål. Når en ser på talla for alle kommunene i unders $\emptyset$ kelsen, svarer $18 \%$ at de bruker både nynorsk og bokmål på nettsidene sine (ibid.: 8). Unders $\varnothing$ kelsen er uklar på flere punkt, blant anna på svarfordelinga mellom gruppene av kommuner som inngår i materialet. Den gir likevel et klart inntrykk av at nynorsken står sterkere i nynorskkommuner enn i de få språknøytrale kommunene som deltok.

7. Dette fører til at bildet av målbruken i kommuner som svarer at de har nynorsk som målvedtak, blir «noko unøyaktig» (Språkrådet et al. 2011: 2). 
I en rapport utarbeida for Noregs Mållag gir Lilleholt og Kihl (2014) en historisk oversikt over nynorskens posisjon gjennom tidligere endringer i kommunestrukturen. Deres hovedfunn i rapporten er at tidligere sammenslåinger har gått hardt ut over nynorsken. Lilleholt og Kihl frykter at nynorsken vil komme dårlig ut med kommunereformen i 2020 også, og peker på konkrete geografiske områder hvor de meiner at nynorsk er mest pressa:

Nynorsken er mest truga der han stod svakt frå før - i randsonene på Austlandet, Sørlandet og Nord-Møre [sic], i tillegg til rundt dei store vestlandsbyane, særleg Ålesund, Haugesund og Stavanger/Sandnes. Til saman representerer dette eit alvorleg trugsmål mot det fotfestet nynorsken har i Noreg. (Lilleholt og Kihl 2014: 21)

De nynorskområdene som Lilleholt og Kihl her utpeker som særlig sårbare, er områder som vi også har et særlig blikk på i vår kartlegging og drøfting av målformpraksis på kommunenes nettsider.

I ei drøfting av hva som trengs for å sikre et språk under press, her nynorsk, tar Gramstad (2019) opp hva som bør gjøres på ulike forvaltningsnivå. Gramstad viser til at flere offentlige organ får større geografiske virkeområder, og at dette «vil føra til fleire såkalla språkleg nøytrale forvaltningsområde» (Gramstad 2019: 27). Han fastslår at i slike områder er bokmål i praksis blitt dominerende, og at "[e]in auke i språkleg nøytrale område betyr såleis mindre bruk av nynorsk» (ibid.). Derfor meiner Gramstad at en må vurdere å innføre kvoteordninger for bruk av nynorsk i språklig nøytrale områder. Sammenslåing av kommuner vil føre til sentralisering og mindre bruk av den minst brukte målformen. Gramstad peker også på at «[k]ommunal sektor er i dag unnateken frå konkrete reglar om språkbruk, bortsett frå på utdanningsfeltet» (ibid.). Det er ikke gode grunner for at kommunal sektor skal være unntatt fra regler om språkvern og språkbruk, meiner Gramstad.

\subsection{Nyere språkpolitiske dokumenter}

I stortingsmeldinga Målog meining (2007-2008) uttrykte Stoltenbergregjeringa at «[d]et overordna målet for språkpolitikken må difor vera å sikra det norske språkets posisjon som eit fullverdig, samfunnsberande språk i Noreg» (Kultur- og kyrkjedepartementet 2008: 14). Videre pekte regjeringa på at den ville legge til rette for likestilling mellom bokmål og 


\section{Tom Flaten og Magnhild Vollan}

nynorsk. For å nå disse måla foreslo regjeringa flere tiltak som Stortinget stilte seg bak. Blant anna blei det understreka at bindende målbruksregler kun finnes for staten og statlige organ, men som et tiltak ville en at kulturdepartementet skulle gjennomgå og greie ut «om det bør vera nærare målbruksreglar også for kommunesektoren» (ibid.: 51). Sjøl om det ikke har kommet slike regler, er det liten tvil om at denne stortingsmeldinga er en sentral premissleverand $\varnothing \mathrm{r}$ for målformsituasjonen i dag.

Arbeidet med ny språklov er på samme måte relevant i denne sammenhengen. Den 12. mai 2020 la Solberg-regjeringa fram forslag til ny språklov og ny stortingsmelding om språk. Innledningsvis posisjonerer regjeringa seg med en offensiv og heilhetlig språkpolitikk:

Med denne proposisjonen vil regjeringa leggje grunnlaget for ein offensiv språkpolitikk som omfattar dei språka den norske staten har ansvar for. Eit hovudmål med språkpolitikken er å sikre norsk som hovudspråket i Noreg, som samfunnsberande språk for heile landet, og som forvaltningsspråk $i$ alle sektorar. (Kulturdepartement 2020: 7)

Videre fastslås det at «[s]jølv om skriftspråka bokmål og nynorsk heilt sidan jamstillingsvedtaket i 1885 har vore formelt jamstilte, er mindretalsspråket nynorsk stadig utsett for press frå bokmål» (ibid.: 10). Det understrekes at språkpolitikken skal fremme reell jamstilling mellom de to skriftspråka, og at «[d]et offentlege har eit særleg ansvar for å fremje nynorsk som det minst bruka språket. Dette inneber at situasjonen for nynorsk som mindretalsspråk blir vurdert særskilt, til dømes i politikkutvikling eller regelverksarbeid som gjeld norsk språk» (ibid.). Vi ser her at det er en prinsipiell forskjell $i$ jamstillingsbegrepet $i$ de to stortingsmeldingene, ved at 2020-meldinga særlig st $\varnothing$ tter mindretallsmålformen. Et viktig punkt i lovarbeidet har også vært knytta til spørsmålet om den nye språklovas virkeområde. Dette drøftes i meldingsdelen (ibid.: 9798). Mållova (1980) sitt virkeområde omfatter kun statsorgan, men i regjeringas forslag til ny språklov vil fylkeskommunene få et større ansvar, mens kommunene fortsatt ikke vil bli en del av virkeområdet (ibid.: 98). 


\section{Materiale og metode}

Materialet består av registreringer av målformbruken fra utvalgte kommunale nettsider. Materialet er todelt, både fordi innsamlingsarbeidet blei gjort til ulik tid og fordi utvalget er ulikt. Del 1 blei samla inn høsten 2019, mens del 2 blei samla inn våren 2020.

Del 1 utgjør hoveddelen og består av registreringer fra nettsidene til 271 kommuner. De kommunene som inngår i materialet, hadde enten valgt nynorsk som sin målform ${ }^{8}$ eller var språklig nøytrale. Det er altså ikke gjort registreringer for de resterende 151 kommunene som hadde valgt bokmål som sin målform. Denne avgrensinga er gjort fordi det etter vår vurdering ikke er av interesse å unders $\varnothing$ ke målformbruken på bokmålskommunenes nettsider. Det er høyst sannsynlig at disse kommunene bruker bokmål i kommunikasjonen «utover» til innbyggerne (jf. også Tvitekkja 2010). Dette har sammenheng med at opplæringsmålformen er bokmål. Tabell 1 viser at alle grunnskoleelevene i ni fylker har bokmål som opplæringsmålform. Videre gir kartet i figur 2 sammen med tabell 2 et inntrykk av åssen målvedtaka fordeler seg geografisk.

\begin{tabular}{|l|c|c|c|}
\hline Fylke & Nøytrale & Nynorsk & Bokmål \\
\hline Østfold & 2 & 0 & 16 \\
\hline Akershus & 5 & 0 & 17 \\
\hline Oslo & 1 & 0 & 0 \\
\hline Hedmark & 7 & 0 & 15 \\
\hline Oppland & 10 & 7 & 9 \\
\hline Buskerud & 5 & 3 & 13 \\
\hline Vestfold & 3 & 0 & 6 \\
\hline Telemark & 9 & 8 & 1 \\
\hline Aust-Agder & 7 & 4 & 4 \\
\hline Vest-Agder & 6 & 2 & 7 \\
\hline Rogaland & 12 & 11 & 3 \\
\hline Hordaland & 3 & 30 & 0 \\
\hline Sogn og Fjordane & 0 & 26 & 0 \\
\hline Møre og Romsdal & 12 & 22 & 1 \\
\hline Trøndelag & 36 & 0 & 12 \\
\hline Nordland & 21 & 0 & 23 \\
\hline Troms & 15 & 0 & 9 \\
\hline Finnmark & 4 & 0 & 15 \\
\hline Til sammen & 158 & 113 & 151 \\
\hline
\end{tabular}

Tabell 2: Fordeling av målvedtak i kommunene etter fylke, per 31.10.2019.



Figur 2: Kart over målvedtak (Bolstad 2016).

8. Disse kommunene omtales nedenfor også som nynorskkommuner. 
Del 1 av materialet består av 271 maler og 1314 nyhetssaker i alt. Registreringsarbeidet blei utført i løpet av to dager i oktober 2019, og skjedde i to operasjoner. Først blei målformbruken i nettsidenes mal, altså de faste elementene på forsida som overskrifter og menypunkt, registrert og dokumentert. Deretter registrerte og dokumenterte vi målformbruken i de fem siste nyhetssakene på nettsidene. Dokumentasjonen består av skjermbilder av både forsida på hver nettside og av hver enkelt nyhetssak. Nyhetssakene er henta fra menypunkt kalt «nyheter», «aktuelt» eller liknende. Enkelte nettsider hadde færre enn fem nyhetssaker, og der registrerte vi alle tilgjengelige nyhetssaker. De ulike delene av materialet blei lagra digitalt og koda.

Del 2 av materialet består av registreringer av målformbruken på nettsidene til seks nye kommuner, sammenslått fra 1.1.2020. Disse kommunene består av til sammen atten tidligere kommuner. Felles for de nye kommunene er at deres tidligere kommuner hadde ulike målvedtak, der minst én kommune hadde vedtak om nynorsk. Disse seks kommunene er det totale antallet nyetablerte kommuner som kan beskrives på denne måten. I tabell 3 gis en oversikt over kommunene og de atten tidligere kommunene som de består av.

Del 2 av materialet består av 6 maler og 60 nyhetssaker i alt. Registreringsarbeidet blei gjort i mai 2020, og fulgte samme retningslinjer som i del 1, med én forskjell idet antall nyhetssaker blei utvida fra fem til ti per kommune. Denne utvidelsen hadde som formål å skaffe et større materiale fra de nye kommunenes nettsider. På denne måten får vi et bedre empirisk grunnlag til å drøfte Gramstad (2019) og Lilleholt og Kihl (2014) sine synspunkt om språklige konsekvenser ved kommunesammenslåinger.

Innsamlinga var reint deskriptiv idet vi kun registrerte målform uten for eksempel å vurdere språklig korrekthet eller liknende. Det oppsto imidlertid utfordringer ved maler og nyhetssaker hvor det var vanskelig å bestemme hvilken målform som var brukt, fordi vi der fant innslag av både bokmål og nynorsk. I registreringsskjemaene hadde vi tatt høyde for dette ved å legge inn «blanda mal» for nettsider som brukte både nynorsk og bokmål i faste elementer på sine forsider. For nyhetssakene hadde vi ikke en slik blandingskategori, men vurderte hvilken målform som dominerte, og registrerte denne.

Vårt materiale er omfattende og mangfoldig. I analysen har vi derfor valgt å bruke deskriptiv statistikk som er «eit hjelpemiddel for å avdekke 
Tabell 3: Oversikt over kommunene som del 2 av materialet er henta fra.

\begin{tabular}{|c|c|c|c|}
\hline \multirow{2}{*}{$\begin{array}{l}\text { Seks nye kommuner per } 1 \text {. januar } \\
2020 \text {, fordelt etter målvedtak }\end{array}$} & \multicolumn{3}{|c|}{ De 18 tidligere kommunene, fordelt etter målvedtak } \\
\hline & bokmål & språklig nøytral & nynorsk \\
\hline \multicolumn{4}{|l|}{ Språklig nøytrale kommuner: } \\
\hline Sandnes & & Sandnes & Forsand \\
\hline Stavanger & Stavanger & Rennes $\varnothing y$ & Finn $\varnothing y$ \\
\hline Molde & & Molde & $\begin{array}{l}\text { Nesset } \\
\text { Midsund }\end{array}$ \\
\hline \multicolumn{4}{|l|}{ Nynorskkommuner: } \\
\hline Midt-Telemark & & Sauherad & $\mathrm{B} \varnothing$ \\
\hline Ullensvang & & Odda & $\begin{array}{c}\text { Ullensvang } \\
\text { Jondal }\end{array}$ \\
\hline Ålesund & & Ålesund & $\begin{array}{l}\text { Ørskog } \\
\text { Skodje } \\
\text { Haram } \\
\text { Sandøy }\end{array}$ \\
\hline
\end{tabular}

og synleggjere den informasjonen som ligg i eit slikt materiale» (Befring 1994: 161). Når resultata presenteres, faller det naturlig å framstille mye informasjon gjennom tabeller, mens de viktigste funna kommenteres i løpende tekst. Registreringene av målformbruk er systematisert ut fra om kommunen hadde valgt nynorsk som målform eller var språklig nøytral.

Ettersom studien er basert på et todelt materiale, brukes den fylkesog kommuneinndelinga som gjaldt i 2019 i presentasjonen av materialets del 1. I presentasjonen av materialets del 2 er den nye kommuneinndelinga presisert.

\section{Resultater}

Resultatpresentasjonen faller i tre deler. De to første delene presenterer hovedfunn i henholdsvis del 1 og del 2 av materialet. I den tredje delen presenteres de to målformenes posisjon før og etter kommunesammenslåingene. I alle delene presenteres først målformbruken i malene på de kommunale nettsidene, deretter målformbruken i nyhetssakene. Presentasjonen begynner med overordna resultater og går videre med nærmere konkretisering og eksemplifisering. 


\subsection{Hovedfunn $i$ del 1 av materialet}

Nedenfor presenteres hovedfunn gjort i materialets del 1 som blei samla inn høsten 2019 i et utvalg som består av 158 språknøytrale kommuner og 113 nynorskkommuner.

\subsubsection{Målformbruk i nettsidemalene}

Et hovedfunn er at nesten alle nettsidemalene til de språknøytrale kommunene er på bokmål. I kommunene med målvedtak om nynorsk står nynorsk sterkt i malene, men bildet er ikke like entydig her.

Tabell 4: Oversikt over målformbruk i nettsidemalene, fordelt etter målformvedtak.

\begin{tabular}{|c|c|c|c|c|c|}
\hline \multicolumn{2}{|c|}{ Språknøytrale kommuner (158) } & \multicolumn{3}{|c|}{ Nynorskkommuner (113) } \\
\hline Nynorsk & Bokmål & Blanda & Nynorsk & Bokmål & Blanda \\
\hline 2 & 155 & 1 & 99 & 4 & 10 \\
\hline
\end{tabular}

Tabell 4 viser at heile 155 av de 158 språknøytrale kommunene bruker nettsidemaler på bokmål, mens to bruker maler på nynorsk. Disse to er Lesja kommune i Oppland og Hå kommune i Rogaland (se vedlegg 2). En kan merke seg at vi i disse to fylkene finner områder som hører til nynorskens randsoner. Det ene eksempelet på bruk av blanda mal hører til i Hordaland som tradisjonelt regnes til kjerneområdet for nynorsk.

For de 113 nynorskkommunenes vedkommende er bildet mer sammensatt. I denne delen av materialet er det 99 nynorskmaler, ti blanda maler og fire bokmålsmaler (se vedlegg 1 og 3). Tabell 5 viser at alle nynorskkommunene i de tre fylkene Oppland, Buskerud og Sogn og Fjordane har nettsidemalen på nynorsk. I Hordaland er det nesten like gjennomført. Funna for Sogn og Fjordane og Hordaland passer godt inn i den tradisjonelle oppfatninga av disse fylkene som del av kjerneområdet for nynorsk. I nynorskkommunene i Møre og Romsdal og Telemark ser vi et betydelig innslag av språklig blanding i malene, mens to nynorskkommuner i Rogaland har bokmålsmal. 
Tabell 5: Nynorskkommunenes målformbruk i nettsidemalene i aktuelle fylker. ${ }^{9}$

\begin{tabular}{|l|c|c|c|}
\hline Fylke & Nynorsk & Blanda & Bokmål \\
\hline Oppland & 7 & 0 & 0 \\
\hline Buskerud & 3 & 0 & 0 \\
\hline Telemark & 6 & 2 & 0 \\
\hline Aust-Agder & 3 & 1 & 0 \\
\hline Vest-Agder & 0 & 1 & 1 \\
\hline Rogaland & 9 & 0 & 2 \\
\hline Hordaland & 29 & 1 & 0 \\
\hline Sogn og Fjordane & 26 & 0 & 0 \\
\hline Møre og Romsdal & 16 & 5 & 1 \\
\hline
\end{tabular}

Så langt har vi sett at malene brukt i de språknøytrale kommunene gjennomgående er på bokmål, uavhengig av hvor kommunene er plassert geografisk. Her kan det tilføyes at de språknøytrale kommunene som har mal på nynorsk, ligger i et tradisjonelt nynorskområde. Videre har vi sett at storparten av malene brukt i nynorskkommunene er utforma på nynorsk, mens en del er utforma i ei blanding av nynorsk og bokmål. Oppsummert framstår de nøytrale kommunene mer entydig som bokmålskommuner enn nynorskkommunene framstår som nynorskkommuner.

\subsubsection{Målformbruk i nyhetssakene}

Nyhetssakene på kommunenes nettsider skal i all hovedsak gi innbyggere og andre informasjon om aktuelle saker som angår kommunen. I vårt materiale ser vi at kommunene innholdsmessig har et nokså breit utvalg av nyhetssaker. Uten at vi har gjort en nærmere analyse av innholdselementene, merker vi oss likevel to typer av nyhetssaker. Den første typen er nyhetssaker som vil forekomme med en viss regelmessighet. Her finner vi blant anna informasjon om valgresultat, influensavaksine og verdensdagen for psykisk helse. Disse nyhetssakene er kobla til tidspunktet på året da materialet blei samla. Den andre typen nyhetssaker er av ad hoc-art og dreier seg om saker som gjelder særskilte aktiviteter i kommunen, som pågående planarbeid, lokale arrangementer eller informasjon om kommunale tjenestetilbud.

9. Her er bare de ni fylkene med kommuner med målvedtak om nynorsk tatt med, jf. tabell 1. 


\section{Tom Flaten og Magnhild Vollan}

Nyhetssakenes bredde, utvalg og innhold kunne i seg sjøl vært tema for et nærstudium, men det faller utenfor i denne sammenhengen. Det viser seg imidlertid at de aller fleste kommunene har regelmessige oppdateringer av nyhetssakene, og videre at de fleste har mange nyhetssaker på nettsidene, hvor et utvalg av nyhetssaker, gjerne 3-4, lå på nettsidenes framside mens de resterende lå i ulike former for nyhetsarkiv. Slik vi har redegjort for i metodedelen, registrerte vi de fem siste nyhetssakene på hver kommunes nettside, eller så mange som var tilgjengelige om det var færre nyhetssaker. Dette ga oss 1314 nyhetssaker i alt.

Tabell 6: Fordeling av nyhetssaker etter målform.

\begin{tabular}{|c|c|c|c|}
\hline Språknøytrale kommuner (760 saker) & \multicolumn{2}{|c|}{ Nynorskkommuner (554 saker) } \\
\hline Nynorsk & Bokmål & Nynorsk & Bokmål \\
\hline $3 \%$ & $97 \%$ & $91 \%$ & $9 \%$ \\
\hline
\end{tabular}

Tabell 6 viser bruken av målform i nyhetssakene i språknøytrale kommuner og i nynorskkommuner. Vi ser umiddelbart at de språkn $\varnothing y$ trale kommunene i all hovedsak bruker bokmål som målform i nyhetssakene. I nynorskkommunene brukes aller mest nynorsk, men der er det også et klart innslag av bokmål. I det videre viser vi den geografiske fordelinga av dette, først for de språknøytrale kommunenes del, deretter for nynorskkommunenes del.

Tabell 7: Fordeling av nyhetssaker etter målform i språknøytrale kommuner i aktuelle fylker.

\begin{tabular}{|l|c|c|c|c|}
\hline & $\begin{array}{c}\text { Antall språklig } \\
\text { nøytrale kommuner }\end{array}$ & Antall nyhetssaker & Nynorsk & Bokmål \\
\hline Oppland & 10 & 50 & 9 & 41 \\
\hline Buskerud & 5 & 23 & 1 & 22 \\
\hline Telemark & 9 & 45 & 1 & 44 \\
\hline Vest-Agder & 6 & 30 & 1 & 29 \\
\hline Rogaland & 12 & 57 & 4 & 53 \\
\hline Hordaland & 3 & 15 & 5 & 10 \\
\hline Møre og Romsdal & 12 & 60 & 3 & 57 \\
\hline
\end{tabular}

I tabell 7 er bare fylker med språknøytrale kommuner som har brukt nynorsk i minst én nyhetssak, tatt med. I de språknøytrale kommunene i 
de fylkene som ikke er med i tabellen, altså i alle de resterende fylkene, inneholder materialet ingen nyhetssaker på nynorsk.

Vi ser at språknøytrale kommuner i Oppland, Hordaland og Rogaland skiller seg ut ved å ha flere nyhetssaker på nynorsk (se vedlegg 5). Unders $\varnothing$ ker en registreringene på kommunenivå, viser det seg at det er én kommune i hvert av de tre fylkene som står for nesten alle disse nyhetssakene på nynorsk. I Oppland har Lesja kommune alle de fem siste nyhetssakene på nynorsk. Det samme gjelder Odda kommune i Hordaland. For Rogalands del står Hå kommune for alle de fire nyhetssakene på nynorsk. Blant de 158 språknøytrale kommunene på landsbasis framstår altså disse tre som unntakskommuner. Dersom en ser bort fra situasjonen i de tre unntakskommunene, er bare $1 \%$ av nyhetssakene i landets språknøytrale kommuner på nynorsk (se vedlegg 6).

Tabell 8: Fordeling av nyhetssaker etter målform i nynorskkommuner i aktuelle fylker.

\begin{tabular}{|l|c|c|c|c|}
\hline Fylke & $\begin{array}{c}\text { Antall nynorsk- } \\
\text { kommuner }\end{array}$ & Antall nyhetssaker & Nynorsk & Bokmål \\
\hline Oppland & 7 & 35 & 29 & 6 \\
\hline Buskerud & 3 & 15 & 14 & 1 \\
\hline Telemark & 8 & 39 & 39 & 0 \\
\hline Aust-Agder & 4 & 12 & 11 & 1 \\
\hline Vest-Agder & 2 & 10 & 6 & 4 \\
\hline Rogaland & 11 & 55 & 35 & 20 \\
\hline Hordaland & 30 & 150 & 148 & 2 \\
\hline Sogn og Fjordane & 26 & 129 & 125 & 4 \\
\hline Møre og Romsdal & 22 & 109 & 98 & 11 \\
\hline
\end{tabular}

I tabell 8 gis opplysninger om de ni fylkene som har nynorskkommuner innenfor sine grenser. Det er altså ingen nynorskkommuner i de $\varnothing$ vrige ni fylkene (se tabell 2). Vi ser i tabell 8 at nynorsk brukes i svært stort omfang i nynorskkommunene i Hordaland. Det samme gjelder Telemark, hvor faktisk alle nyhetssakene i nynorskkommunene er på nynorsk. Sogn og Fjordane har kun nynorskkommuner, og også der er nynorskandelen svært høy. Det er få nynorskkommuner i Buskerud og Aust-Agder, men nynorsken står sterkt i det begrensa materialet. I de to nynorskkommunene i Vest-Agder står nynorsken langt svakere. Tabellen viser altså en svært stor variasjon mellom fylkene, og de tre resterende 
fylkene, Rogaland, Oppland og Møre og Romsdal, har høyere andel bokmålsbruk.

Det fylket som skiller seg særlig ut i så måte, er Rogaland. I nynorskkommunene i Rogaland er godt over 1/3 av nyhetssakene på bokmål. Nyhetssaker på bokmål finner vi i 7 av 11 nynorskkommuner i fylket. I nynorskkommunene i både Oppland og Møre og Romsdal er det også utbredt bokmålsbruk, om enn noe mindre enn i Rogaland. I Oppland er 17 \% av nyhetssakene på bokmål mens det tilsvarende i Møre og Romsdal er $10 \%$. Disse finner vi i 2 av 7 nynorskkommuner i Oppland og 3 av 22 nynorskkommuner i Møre og Romsdal. Dette viser et visst skille mellom bokmålsbruken i nynorskkommuner i Rogaland, hvor den er brei, mens det i Oppland og Møre og Romsdal kun er i enkelte tilsvarende kommuner. Det er verdt å bemerke at områder i disse tre fylkene ligger i randsonen til nynorskens kjerneområder. Det samme kunne en imidlertid også si om nynorskkommunene i Telemark og Buskerud, men disse har en heilt annen bruk av nynorsk.

Her kan det være interessant å se nærmere på innholdet i de sakene som er skrevet på bokmål i nynorskkommunene. Vi ser et mønster i hva slags saker som er utforma på bokmål. Dette gjelder blant anna de nyhetssakene som er pressemeldinger fra eksterne, oftest offentlige, akt $\varnothing$ rer. Et eksempel (vedlegg 4) er når innbyggerne i Møre og Romsdal inviteres til å delta i en spørreunders $\varnothing$ kelse om helse. Det kan være et skille mellom nyhetssaker som kommunen har produsert sjøl, og de som er gjengivelser av pressemeldinger eller liknende fra andre. Nynorskkommuner som grenser til språkn øytrale kommuner eller bokmålskommuner, mottar pressemeldinger og informasjonsskriv som gjelder flere kommuner i regionen, og en del av disse kan være på bokmål slik reglene om flertallsmålformen sier. Igjen er det likevel verdt å merke seg at noen nynorskkommuner uansett ikke har nyhetssaker på bokmål, og det kan tyde på at disse kommunene bevisst unngår å bruke pressemeldinger og informasjonsskriv på bokmål. Vi ser at det er mange nynorskkommuner uten bokmålsbruk som også dels er omgitt av språknøytrale kommuner eller bokmålskommuner, uten at det har satt spor på nettsidene. Eksempler på dette er Nissedal i Telemark og Ål i Buskerud.

\subsubsection{De to målformenes posisjon på kommunale nettsider}

Når det gjelder spørsmålet om samsvar mellom kommunenes målvedtak og målformpraksis på nettsidene, er resultata tydelige. Det viser seg at 
bokmål står svært sterkt i språknøytrale kommuners egen praksis. Med ytterst få unntak bruker disse kommunene bokmål, både i maler og nyhetssaker. Materialet vårt indikerer at språknøytrale kommuner er bokmålskommuner i praksis siden de i ubetydelig grad bruker nynorsk på nettsidene. Dersom vi ser bort fra de tre språknøytrale unntakskommunene (Hå i Rogaland, Lesja i Oppland og Odda i Hordaland), er det bare 1 \% nynorskbruk i nyhetssakene på språknøytrale kommuners nettsider. Når det så gjelder nynorskens stilling i nynorskkommunene, viser det seg at den er særlig sterk i Telemark, Hordaland og Sogn og Fjordane. Nynorskkommunene i disse tre fylkene har nettsider med mer enn 98 $\%$ av nyhetssakene på nynorsk. I de resterende fylkene med nynorskkommuner er nynorskandelen betydelig lavere. Der er i underkant av 78 \% av nyhetssakene på nynorsk, mens drøyt 22 \% er på bokmål.

Gjennom analysen av materialets del 1 blir det altså dokumentert at nynorskkommunene i stor grad bruker nynorsk på nettsidene, mens språknøytrale kommuner i svært liten grad tar i bruk begge målformer når de henvender seg til sine innbyggere på nettet. Praksisen i de to gruppene av kommuner er med andre ord sammenfallende idet en målform dominerer i hver av dem. Når det så gjelder forholdet mellom kommunenes målformpraksis og deres geografiske plassering, gir materialet vårt et målformgeografisk overblikk som viser at bokmål dominerer på kommunenes nettsider, bortsett fra i de tradisjonelle kjerneområdene for nynorsk. Et anna sentralt funn er forekomsten av blanda maler, særlig i nynorskkommuner i nynorskens randsoner.

\subsection{Hovedfunn i del 2 av materialet}

Nedenfor presenteres hovedfunn gjort i materialets del 2 som blei samla inn våren 2020 i seks kommuner. Det dreier seg om tre nyetablerte språknøytrale kommuner (Molde, Sandnes og Stavanger) og tre nyetablerte nynorskkommuner (Midt-Telemark, Ullensvang og Ålesund) (se tabell 3). Prosessene som ligger bak vedtaka, er både interessante og ulike. Det er verdt å se på dem før vi går til hovedfunna.

De språknøytrale kommunene har alle hatt ulike prosesser sjøl om det formelle målvedtaket er likt. Den nye kommunen Molde vedtok 14.11.2019 at kommunen skulle være språklig nøytral. Det blei samtidig vedtatt at «Molde kommune legger vekt på likeverdighet mellom bokmål og nynorsk. Begge målformene skal praktiseres og fullt ut respekteres som kommunens administrasjonsspråk» (Molde kommune 2019). Vi- 
dere sies det i vedtaket at de ansatte i kommunen skal få velge å bruke den målformen de behersker best. I saksframlegget begrunna prosjektrådmannen i Molde dette med at en bør unngå tvang i målspørsmålet og at kommunens medarbeidere vil kommunisere bedre om de får bruke målformen de behersker best.

I Sandnes finner vi i prinsippdokumentet for ny kommune den korte formuleringa «[n]y kommune er språkn $\varnothing y$ tral» under overskriften «Språkform» (Sandnes kommune 2016). Punktet blir ikke diskutert eller begrunna på noe vis i dokumentet. I Stavanger finner vi flere dokumenter som omhandler valg av målform. Arbeidsutvalget for den nye storkommunen vedtok at kommunen skulle være språklig nøytral, både i det formelle målvedtaket og når det gjelder administrasjonsspråk. I saksdokumentene blei følgende lagt til om et eventuelt vedtak om å være språklig nøytral: «En viss bruk av nynorsk på nettsidene til kommunen vil også være en naturlig konsekvens av et slikt vedtak» (Stavanger kommune 2018). Vi ser altså at det er stor forskjell på behandlingene, begrunnelsene og praktiske vurderinger i disse tre kommunene.

For de tre nye nynorskkommunene var også prosessene noe ulike. For Midt-Telemark kommune blei det vedtatt Målbruksplan (2019). I denne planen står det at «[n]ynorsk og bokmål skal vere likestilte målformer [...]» (Midt-Telemark 2019: 1). Videre pekes det på at Midt-Telemark kommune er «ein randsonekommune for bruk av nynorsk, og det er også nynorsk som er under st $\varnothing$ rst press både offentleg og privat» (ibid.: 2). Som vedlegg til planen finner en oversikt over hvilke saksområder som skal benytte hvilken målform. Her kan en for eksempel se at kommuneplanens samfunns- og arealdel skal være på nynorsk, mens $\emptyset$ konomiplan, budsjett, årsmelding og regnskap skal være på bokmål. På kommunens nettside skal begge målformer brukes.

Den nye kommunen Ullensvang gjorde tidlig i prosessen vedtak om nynorsk som målform. Allerede i intensjonsavtalen i 2016 mellom de tre gamle kommunene slås det fast at «[m]ålføret ${ }^{10}$ til den nye kommunen vert nynorsk» (Odda kommune 2016). Det endelige vedtaket blei gjort med stort flertall i november 2019 (Lund 2019).

Den siste nye kommunen, Ålesund, fikk mye oppmerksomhet for sitt målformvalg. Prosessen og debatten var høylytt, og det var ikke opp-

10. Her brukes begrepet «målføre» i stedet for målform. Vi må anta at dette er en misforstått begrepsbruk som ikke er uvanlig. 
lagt at Ålesund skulle bli Norges st $\varnothing$ rste nynorskkommune. Med knapt flertall (40-36) blei nynorsk valgt som kommunens målform i desember 2019 (Ålesund kommune 2019). I vedtaket var det også med et eget punkt om at alt informasjonsmateriell fra kommunen skulle være på nynorsk, inkludert nettsidene. Allerede i oktober 2019, altså før det formelle vedtaket, blei Ålesund kåra til årets nynorskkommune, og juryen uttalte et håp om at "prisen kan bidra til mykje godt nynorskarbeid i den nye storkommunen» (Språkrådet 2019). På forsommeren 2020 blei det satt ned et utvalg som skal lage forslag til språkbruksplan for kommunen, men i skrivende stund er ikke denne klar.

\subsubsection{Målformbruk i nettsidemalene}

Tabell 9 gir informasjon om de seks kommunenes målformbruk i nettsidemalene. Et hovedfunn er at alle de språknøytrale kommunene bruker nettsidemaler på bokmål. I tillegg har også nynorskkommunen MidtTelemark bokmålsmal, mens de to andre nynorskkommunene har nettsidemaler på nynorsk. Ingen av de seks nettsidemalene er blanda.

Tabell 9: Oversikt over målformbruk i nettsidemalene, fordelt etter målformvedtak.

\begin{tabular}{|c|c|c|c|c|c|}
\hline \multicolumn{2}{|c|}{ Språkn $\varnothing$ trale kommuner (3) } & \multicolumn{3}{|c|}{ Nynorskkommuner (3) } \\
\hline Nynorsk & Bokmål & Blanda & Nynorsk & Bokmål & Blanda \\
\hline 0 & 3 & 0 & 2 & 1 & 0 \\
\hline
\end{tabular}

\subsubsection{Målformbruk i nyhetssakene}

Tabell 10 gir oversikt over de seks kommunenes målformbruk i nyhetssakene. Et hovedfunn er at bokmål dominerer i de tre språkn øytrale kommunene og i én nynorskkommune. I både Stavanger og Molde er alle nyhetssakene på bokmål, mens det er registrert én sak på nynorsk i språknøytrale Sandnes. I nynorskkommunene Ullensvang og Ålesund er alle nyhetssakene på nynorsk, mens ni av de ti sakene på nettsidene til nynorskkommunen Midt-Telemark er på bokmål.

Som ved nettsidemalene ser vi tydelig at bokmål har en dominerende posisjon. Det gjelder både for de språknøytrale kommunene og for den ene nynorskkommunen i randsonen. Det er med andre ord nesten fullt samsvar mellom målformpraksis i nyhetssakene og malene. 
Tabell 10: Oversikt over målformbruk i nyhetssaker, fordelt etter målformvedtak.

\begin{tabular}{|c|c|c|c|c|c|}
\hline \multicolumn{2}{|c|}{ Språkn øytrale kommuner (30 saker) } & \multicolumn{2}{|c|}{ Nynorskommuner (30 saker) } \\
\hline & Nynorsk & Bokmål & & Nynorsk & Bokmål \\
\hline Sandnes & 1 & 9 & Midt-Telemark & 1 & 9 \\
\hline Stavanger & 0 & 10 & Ullensvang & 10 & 0 \\
\hline Molde & 0 & 10 & Ålesund & 10 & 0 \\
\hline Til sammen & $\mathbf{1}$ & $\mathbf{2 9}$ & Til sammen & $\mathbf{2 1}$ & $\mathbf{9}$ \\
\hline
\end{tabular}

4.3 De to målformenes posisjon på kommunale nettsider - før og etter 1. januar 2020

Som vist $\mathrm{i}$ tabell 3 blei 18 tidligere kommuner til seks nye kommuner ved årsskiftet. De tidligere kommunene som er blitt del av disse nye, hadde denne målformfordelinga: én bokmålskommune, seks språknøytrale kommuner og elleve nynorskkommuner. Halvdelen av de nye kommunene har gjort målvedtak om nynorsk, mens den andre halvdelen er språklig nøytrale. Gjennom ei sammenstilling av opplysninger fra materialets del 1 og del 2 kommer det fram tydelige tendenser. Det viser seg at bokmål har styrka sin stilling og dominerer heilt i fire av de nye kommunene, mens nynorsk har fått en tilsvarende dominerende stilling i de to andre.

Nettsidene til de nye språknøytrale kommunene Molde, Stavanger og Sandnes har mal på bokmål, i tillegg er alle saker på bokmål, med et lite unntak for Sandnes. Når det gjelder målformpraksis i de tre tidligere kommunene som nåværende Molde består av, brukte både språkn $\varnothing y t r a l e$ Molde og nynorskkommunen Nesset bare bokmål, mens nynorskkommunen Midsund hadde blanda mal og utstrakt bruk av bokmål i nyhetssakene. Materialets del 1 viser altså at bokmål hadde en sterk posisjon på de kommunale nettsidene også før kommunesammenslåinga i dette området. Likedan er det i den nye kommunen Sandnes, som består av en tidligere språknøytral kommune (Sandnes) som bare brukte bokmål, og en nynorskkommune (Forsand) som brukte nynorsk i malen, mens bokmål dominerte i sakene. Utgangspunktet for nyetablerte Stavanger er mer sammensatt, men også her hadde bokmål en sterk posisjon i målformpraksis før sammenslåinga, og denne posisjonen er blitt styrka etter 
sammenslåinga. Tidligere Stavanger kommune var bokmålskommune ${ }^{11}$ og er nå slått sammen med en nynorskkommune (Finnøy) og en språknøytral kommune (Rennesøy). Materialets del 1 viser at bokmål blei brukt på nettsidene til Rennes $\varnothing y$ kommune, mens Finn $\varnothing y$ kommune hadde både mal og saker på nynorsk.

Når det gjelder de tre nye nynorskkommunene, har vi i punkt 4.2 sett at Midt-Telemark skiller seg ut ved at den likner mer på en språknøytral kommune i sin målformpraksis, idet både mal og ni av ti nyhetssaker er på bokmål. Denne kommunen består av to tidligere kommuner, en nynorskkommune $(\mathrm{B} \varnothing)$ og en språknøytral kommune (Sauherad). Materialets del 1 viser at $\mathrm{B} \varnothing$ hadde blanda mal og alle nyhetssakene på nynorsk, og videre at Sauherad brukte bokmål både i mal og nyhetssakene. Etter kommunesammenslåinga har med andre ord bokmål styrka sin stilling markert, trass i målvedtak om nynorsk. Denne praksisen kan ha sammenheng med at den nye kommunen ennå ikke har kommet ordentlig $\mathrm{i}$ gang med å praktisere sitt målformvedtak. For en del ansatte vil vedtaket føre til at disse må endre språklig praksis, og dette kan ta tid.

Den nye kommunen Ullensvang består av to tidligere nynorskkommuner (Ullensvang og Jondal) som hadde mal og alle nyhetssaker på nynorsk høsten 2019, og språknøytrale Odda som også hadde alle nyhetssakene på nynorsk, mens malen var blanda. Denne kommunen ligger i nynorskens kjerneområde, og denne målformen opprettholder sin sterke posisjon etter sammenslåinga. Den nye nynorskkommunen Ålesund består av fire tidligere nynorskkommuner ( $\varnothing$ rskog, Skodje, Haram og Sand $\varnothing$ ) og en språknøytral kommune (Ålesund). Materialets del 1 viser at de fire tidligere nynorskkommunene brukte nynorsk både i malene og alle nyhetssakene høsten 2019, mens den språknøytrale kommunen hadde både mal og fire av fem nyhetssaker på bokmål. I dette området har nynorsk ikke bare opprettholdt sin posisjon, men til og med styrka den etter sammenslåinga. Ålesunds omland hører tradisjonelt til kjerneområdet for nynorsk som del av Sunnmøre, mens Molde i Romsdal ligger i randsonen. Deres ulike målvedtak og ulike målformpraksiser reflekterer dette.

11. Materialets del 1 inneholder derfor ingen opplysninger om målformpraksis i tidligere Stavanger. 


\subsection{Oppsummering}

Gjennom denne studien dokumenteres flere sider ved forholdet mellom målvedtak og målformpraksis. Det kom tydelig fram at bokmål står sterkt i de språknøytrale kommunene. Materialet fra de kommunale nettsidene indikerer at språkn $\varnothing$ ytrale kommuner er bokmålskommuner i sin målformpraksis, idet det er bokmål som brukes i både maler og nyhetssaker. I materialets del 1 er bokmål brukt i 98 \% av malene og $97 \%$ av nyhetssakene i de språknøytrale kommunene. Ser vi bort fra de tre språknøytrale unntakskommunene (Hå, Lesja og Odda), viser det seg at bokmål brukes i heile 99 \% av nyhetssakene. Konklusjonen er derfor at de språklig nøytrale kommunene er bokmålskommuner i praksis, og det i langt større grad enn nynorskkommuner er nynorskkommuner i sin praksis.

Studien dokumenterer nynorskbruken på kommunale nettsider i nynorskkommuner. I materialets del 1 er nynorsk brukt i $88 \%$ av malene og $91 \%$ av nyhetssakene i alle nynorskkommunene sett under ett. Ser vi nærmere på nynorskens kjerneområde, Sogn og Fjordane og nynorskkommunene i Hordaland, er 98 \% av både malene og sakene på nynorsk. I de resterende fylkene med nynorskkommuner er nynorskens posisjon mer vaklende. I de $\varnothing$ vrige nynorskkommunene, utenom Telemark, er drøyt $22 \%$ av sakene på bokmål på nynorskkommunenes nettsider. Konklusjonen er at det er stor forskjell mellom nynorskkommunene.

Videre gir studien en dokumentasjon av utviklingstrekk når det gjelder målvedtak og målformpraksis etter kommunesammenslåingene ved årsskiftet 2019-2020. Av de seks nye kommunene har tre fatta vedtak om nynorsk, mens de andre tre er språklig nøytrale. Allerede her er det rimelig å anta at nynorsk vil komme under press i den nye kommunehverdagen. Det er da også et tydelig funn at de tre nye språknøytrale kommunene bruker bokmål som målform, både i mal og nyhetssaker, sjøl om de omfatter tidligere kommuner med vedtak om nynorsk. Videre ser vi at de to nye nynorskkommunene som ligger i nynorskens kjerneområde, bruker nynorsk både i mal og saker, mens den tredje nye nynorskkommunen, som ligger i nynorskens randsone, bruker bokmål både i mal og saker. Slik bekreftes Gramstads konklusjon om at ei $\varnothing$ kning i språklig nøytrale områder betyr mindre bruk av nynorsk og mer bruk av bokmål (Gramstad 2019). 


\section{Drøfting}

Nedenfor svarer vi først på problemstillinga og viser hvilke implikasjoner våre funn får for målformkartet over Norge. Deretter dreier drøftinga seg i hovedsak om å se funna i lys av tidligere arbeider, og ikke minst unders $\varnothing$ ke begrepet språklig nøytral kommune ut fra relevante aspekter i språkrettighetsteori.

\subsection{Er det samsvar mellom målvedtak og målformpraksis?}

Når det gjelder denne artikkelens hovedspørsmål om grad av samsvar mellom kommunenes målformvedtak og deres målformpraksis på de kommunale nettsidene, er det mulig å trekke tydelige konklusjoner for ulike kommunegrupper på bakgrunn av funna i materialets del 1 og 2 . For de nynorskkommunene som hører til i det nynorske kjerneområdet, kan en fastslå at det er et sterkt samsvar mellom vedtak og praksis. For nynorskkommuner i nynorskens randsoner er samsvaret langt svakere og mangelfullt. Her er det flere kommuner som bruker bokmålsmal eller blanda mal og har et vesentlig antall nyhetssaker utforma på bokmål. For de språklig nøytrale kommunene er det ikke samsvar mellom vedtak om å være språklig nøytral og en målformpraksis der en nesten utelukkende bruker bokmål på sine nettsider.

Med henvisning til den tidligere omtalte unders $\varnothing$ kelsen av målbruken i nynorskkommunene og utvalgte språknøytrale kommuner (Språkrådet et al. 2011) kan kanskje noe av det mangelfulle samsvaret mellom målvedtak og målformpraksis forklares med at noen av kommunene har ansatte som ikke veit hva kommunens målvedtak er, eller som ikke veit hva målvedtaket innebærer.

I møte med en betydelig andel nynorskkommuners bruk av bokmålsmal og blanda mal på nettsidene kan en undre seg over om en slik praksis er uttrykk for manglende rettskrivingskompetanse eller manglende språklig bevissthet. KS (2019) viser at det er en oppmerksomhet knytta til utforming av kommunale nettsider. De har likevel mest vekt på tekniske og strukturelle aspekter ved nettsidene. Det språklige fokuset begrenser seg hovedsakelig til omtale av klart språk. Ansvarsfordelinga i arbeid med maler og nettsideinnhold kan være uklar (Grønntun 2010). Slike forhold kan gi en inkonsekvent målformbruk.

Grønvik (1987) peker på at delt målformpraksis var intensjonen blant noen språklig nøytrale kommuner etter at mållova blei innført i 1930. 
Vi har dokumentert at denne intensjonen ikke blir oppfylt i og med at de språknøytrale kommunene er bokmålskommuner i sin nettsidepraksis. Det reelle målformkartet er derfor ikke slik kartet over målvedtaka (figur 2) antyder, men heller slik vår redigerte versjon av kartet (figur 3) viser. Språklig nøytrale kommuner finnes i så måte ikke. De ser ut til å være bokmålskommuner i alt anna enn vedtak. Det Grønvik (1987) løfter fram som uklart, nemlig hva det innebærer at en kommune

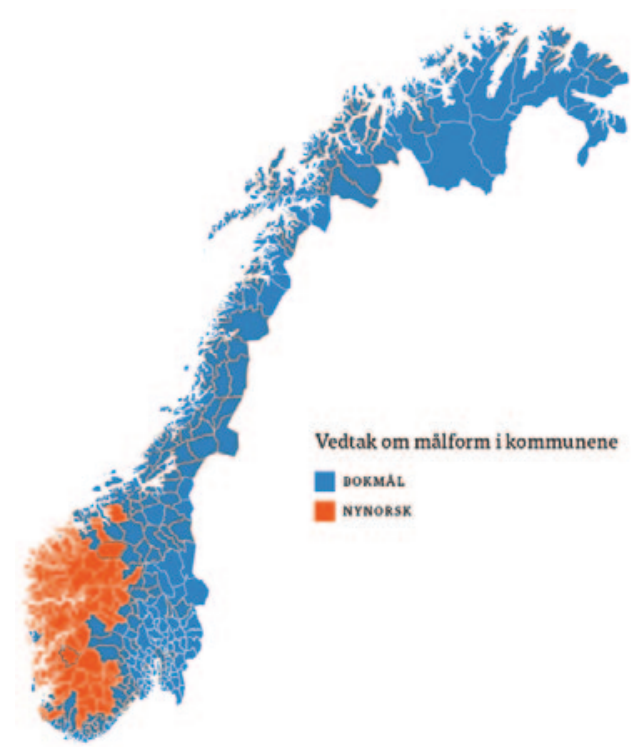

Figur 3: Målformkart (Bolstad 2016, redigert). er språklig nøytral, virker ikke like uklart i dag. Språklig nøytrale kommuner bruker bokmål i sin kommunikasjon på nettsidene, nesten heilt gjennomf $\varnothing r t$.

Den sterke $\phi$ kninga av språklig nøytrale kommuner i sammenslåingsprosessene på 1960-tallet blei etterfulgt av ei betydelig $\varnothing \mathrm{kning}$ av andelen bokmålskommuner de neste tiåra (figur 1). Grunnen til at kommunene blei nøytrale, var at bokmål i realiteten hadde fått større plass som bruksspråk (Gramstad 2019). Av demografiske og kulturelle årsaker blei bokmålets plass stadig større, noe som igjen førte til et språkpolitisk skifte til bokmål. Talla over målvedtak i kommunene viser at andelen språklig nøytrale kommuner $\varnothing$ kte igjen fra 2019 til 2020. Kan vi så forvente samme utvikling som etter forrige store kommunereform, nemlig at bokmål styrker sin posisjon de neste tiåra? En kan fortsatt tenke seg kommuner som velger å være språklig nøytrale for å unngå målstrid, uten å si at de er «likesæl[e] med målform» (Grønvik 1987: 242).

I materialets del 2 ser vi tydelig en overgang fra vedtak om nynorsk til språklig nøytral. Av de 18 gamle kommunene i del 2 var elleve nynorskkommuner, altså mer enn $60 \%$. Etter vedtaka er det tre nynorskkommuner blant de seks nye kommunene, mens praksis på nettsidene viser at kun to kommuner bruker nynorsk, altså 33 \%. Det gir nesten ei 
halvering. Med tanke på at nynorsk er vedtatt i en stor kommune, Ålesund, er ikke nedgangen etter folketall så bratt. Likevel er den geografiske utbredelsen til nynorsk klart svekka, både i Rogaland og Telemark. I så måte hadde Lilleholt og Kihl (2014) rett i sine spådommer om at nynorsken var trua i randsonene. Kommunereformen må dermed sies å ha svekka nynorskens posisjon, med Ålesund som et enslig unntak.

Det fastslås som en kjensgjerning at «mindretalsspråket nynorsk stadig [er] utsett for press frå bokmål» (Kulturdepartementet 2020: 10). Lunde (2020: 119) beskriver den nynorske målformen i tradisjonelle nynorskkommuner som lokal majoritet og nasjonal minoritet. Denne opposisjonen kan bidra til å forstå forholdet mellom målformvedtak og variasjonene i målformpraksis. De samfunnsfaktorene som står særlig sentralt her, er på den ene sida offisiell språkpolitikk og på den andre sida den sentraliseringa som skjer når mindre enheter slås sammen til større (Gramstad 2019).

\subsection{Språklig nøytral kommune}

Det har vært et mål for oss å skape en tydeligere forståelse av hva en språklig nøytral kommune er i praksis. Våre empiriske funn viser klart at de aller fleste språklig nøytrale kommuner bruker bokmål på sine nettsider, og unntaka er få. En bør imidlertid også se på begrepet i et mer overordna perspektiv.

Vi har vist åssen språknøytralitet har vært diskutert og definert innen språkrettighetsteori (Bjørhusdal 2014). Statlig norsk språkpolitikk har vært prega av nøytralitetstenking. Språkn øytralitet er mest drøfta som del av en nasjonal politikk, og ikke på kommunenivå. En fullt ut språklig nøytral stat er ikke mulig (Patten og Kymlicka 2003). Det samme gjelder kommunene som gjennom aktiv kommunikasjon med sine innbyggere vil måtte uttrykke seg gjennom skriftspråket. Slik sett vil også kommunene vanskelig kunne være språknøytrale i samband med målformene. Det er tydelig at språknøytralitet framstår som et utfordrende prosjekt i offentlig forvaltning. At vi har kommuner som etter vedtak er språklig nøytrale, kan derfor se ut som et paradoks.

Vi har imidlertid sett åssen språknøytralitet kan deles i en negativ og en positiv nøytralitet. Den første av disse kaller Bjørhusdal (2014) «velmeinande likesæle». Kommuner som valgte å stå utenfor målstriden ved å ikke ta et standpunkt om kommunalt tjenestemål etter mållova i 1930, kan oppfattes som å ha valgt ei tilnærming knytta til «velmeinande 
likesæle». De фnska at språkbrukerne sjøl skulle ta valget om målform, og at myndighetene, her kommunene, ikke skulle blande seg inn. Om det samme kan sies om de nye kommunene som blei språklig nøytrale etter kommunereformen i 2020, er kanskje mer diskutabelt.

Positiv nøytralitet er knytta til begrepet «raus rettferd» (Bjørhusdal 2014). Offentlig norsk språkpolitikk var i størstedelen av 1900-tallet prega av denne typen språkn øytralitet ved at en fors $\varnothing$ kte å behandle skriftspråka så likt som mulig. Spørsmålet er om de språklig nøytrale kommunene har gjort det samme. Vårt tydelige funn er at språklig nøytrale kommuner $\mathrm{i}$ all hovedsak kun har valgt å ta i bruk bokmål på sine nettsider. På denne måten kan det hevdes at språklig nøytrale kommuner ikke lever opp til denne måten å forstå språknøytralitet på. I den grad disse kommunene preges av en form for språknøytralitet, vil den ligge nærmere «velmeinande likesæle».

Når en kommune fatter vedtak om å være språklig nøytral, kan det være uttrykk for en demokratisk tankegang, gjensidig respekt og toleranse. Et slikt vedtak har derfor ofte vært ei kompromissløsning. De språknøytrale kommunenes målformpraksis som er dokumentert i denne studien, kan forstås å være i overensstemmelse med Gramstads konklusjon om at ei $\varnothing$ kning i språklig nøytrale områder betyr mindre bruk av nynorsk idet bokmål blir dominerende (Gramstad 2019). Han foreslår kvoteordninger for bruk av den minst brukte målformen, som regel nynorsk, også i språklig nøytrale kommuner. Slike mulige pålegg for å sikre mindretallets språk peker i ei anna retning enn språknøytralitet, og kjennes igjen i det Bjørhusdal (2014) kaller språksikringpolitikk.

Ei slik ordning som Gramstad skisserer, med kvoter, ville muligens bidra til å gjøre begrepet språklig nøytral kommune mer forståelig utad. Ved å bruke både nynorsk og bokmål i utoverretta skriving ville de språknøytrale kommunene kunne leve opp til forventningene om å være upartiske. Vi kan se for oss at den allmenne forventninga til begrepet språklig nøytral kunne bli oppfylt på denne måten. Om ei slik løsning med kvoter er mulig og $\emptyset$ nskelig, er derimot et politisk spørsmål. Det er imidlertid fullt mulig å tenke seg at dagens situasjon uten føringer for kommunene i mållova nettopp åpner for den friheten som trengs i begrepet språklig nøytral. Det kommer i det heile an på hvilken innfallsvinkel en har til språknøytralitet, «raus rettferd» eller «velmeinande likesæle». 


\subsection{Sluttord}

For å illustrere utfordringa knytta til begrepet språklig nøytral kommune viser vi framstillinga i læreverket Salto 4 for norsk i grunnskolen (figur 4). Der fortelles det om tre målformvirkeligheter, hvor de sier at «[g]rått felt betyr at det skrives både bokmål og nynorsk» (Bjerke, Fjeld \& Svanes 2016: 150). Sjøl om læreverkets framstilling er del av et anna domene, viser denne formuleringa tydelig hvor vanskelig det kan være å presentere målformsituasjonen når vedtak, praksis og begreps-

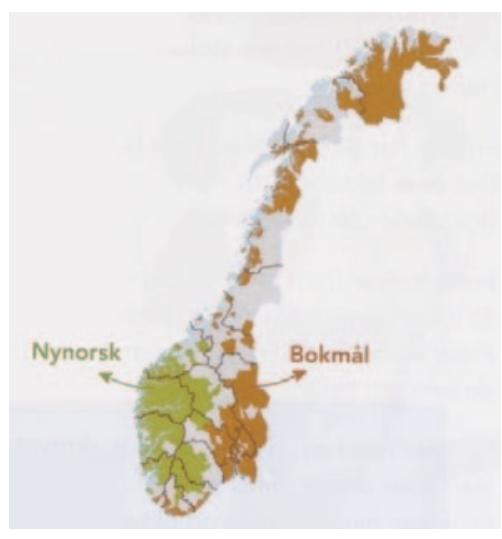

Figur 4: Bjerke, Fjeld Q Svanes (2016: 150). bruk ikke samsvarer.

Vi har gitt et tidsbilde av målformpraksis i kommuner som var språklig nøytrale eller som var nynorskkommuner i overgangen fra 2019 til 2020. Ettersom del 2 av vår studie er gjort kort tid etter kommunesammenslåingene, vil det være særlig interessant å følge de seks nye kommunene videre. En breiere unders $\varnothing$ kelse av disse kommunenes målformpraksis på flere arenaer vil kunne være et viktig forskningsobjekt. Generelt skiller kanskje målformpraksisen på nettsidene seg fra andre teksttyper i kommunene. Om dette finnes det foreløpig lite kunnskap.

Vi har belyst språknøytralitet, og meiner at begrepet språklig nøytral kommune er problematisk, i alle fall slik kommunene med dette vedtaket praktiserer målformene på nettsidene. Språklig nøytral kommune gir et uriktig bilde av den språklige tilstanden, og er med på å skape et mer heterogent inntrykk av den norske språksituasjonen enn det som er virkeligheten.

\section{Referanser}

Befring, Edvard. 1994. Forskingsmetode og statistikk. Oslo: Det Norske Samlaget. 


\section{Tom Flaten og Magnhild Vollan}

Bjerke, Kari Kolbjørnsen, Siv Monica Fjeld \& Ingvill Krogstad Svanes. 2016. Salto 4. Elevbok B. Oslo: Gyldendal Undervisning.

Bjørhusdal, Eli. 2014. Mellom nøytralitet og språksikring: Norsk offentleg språkpolitikk 1885-2005. Oslo: Universitetet i Oslo. http://hdl. handle.net/11250/220171 [Lasta ned 19.01.2021]

Bjørhusdal, Eli. 2015. Nøytralitet eller nynorsk? Språkpolitiske hovudprinsipp i norsk opplæring. I: Nye røyster inynorskforskinga, red. Hjalmar Eiksund \& Jan Olav Fretland, 104-119. Oslo: Det Norske Samlaget.

Bjørhusdal, Eli. 2016. Strategiar for språkleg velferd. I: Offentleg sektor $i$ endring. Fjordantologien 2016, red. Jørgen Amdam m.fl., 97-113. Oslo: Universitetsforlaget.

Bokmålsordboka. 2020. https://ordbok.uib.no/ [Lasta ned 02.06.2020] Bolstad, Erik. 2016. Målvedtak $i$ kommunene. https://snl.no/



Carens, Joseph H. 2000. Culture, citizenship, and community. A contextual exploration of justice as evenhandedness. Oxford: Oxford University Press.

Gramstad, Sigve. 2019. Kva trengst for å sikra eit språk under press? Språknytt 2020 (hefte 2), 24-27.

Gramstad, Sigve \& Kåre Lilleholt. 1983. Lov om målbruk i offentleg teneste - med kommentarar. Oslo: Universitetsforlaget.

Grepstad, Ottar. 2005. Nynorsk faktabok 2005. Hovdebygda: Nynorsk kultursentrum.

Grunnskolenes Informasjonssystem (GSI). 2020. https://gsi.udir.no/ app/\#!/view/units/collectionset/1/collection/83/unit/1/ [Lasta ned 02.06.2020]

Grønntun, Marit. 2010. Universell utforming av kommunale hjemmesider. Upubl. masteroppgave, Avdeling for forvaltningsinformatikk, Universitetet i Oslo. https://www.duo.uio.no/handle/10852/22959 [Lasta ned 20.01.2021]

Grønvik, Oddrun. 1987. Målbruken i offentlig teneste i tida 1930-1940. Oslo: Det Norske Samlaget.

Indre Fosen kommune. 2019. Artikkel til hjemmesiden. https://www. indrefosen.kommune.no/for-ansatte/sprakprofil-klart-sprak/skriverad-for-ulike-sjangre/artikler-til-hjemmesiden/ [Lasta ned 21.01.2021] 
KS. 2019. Egen terminologi for kommunale nettsider. https://www. ks.no/fagomrader/digitalisering/felleslosninger/egen-terminologifor-kommunale-nettsider/ [Lasta ned 21.01.2021]

Kulturdepartementet. 2020. Lov om språk (språklova). (Prop. 108 L. (2019-2020)). https://www.regjeringen.no/contentassets/92cocb2 b2oba4d2aac3c397c54046741/nn-no/pdfs/prp2019202001080oo dddpdfs.pdf [Lasta ned 19.01.2021]

Kultur- og kyrkjedepartementet. 2008. Mål og meining: Ein heilskapleg norskspråkpolitikk. (Meld. St. 35 (2007-2008)). Oslo: Kultur- og kyrkjedepartementet.

Lilleholt, Kåre \& Jens Kihl. 2014. Rapport om kommunereforma - frå Askvoll til Åseral. Oslo: Noregs Mållag.

Lund, Eli. 2019, 11. november. Valde nynorsk som målform i den nye kommunen. Hardanger Folkeblad, 5.

Lunde, Kirsti. 2020. Lokal majoritet, nasjonal minoritet: Ein studie av skriftspråkskifte i robuste nynorskkommunar. I: Vilkår for nynorsk mellom barn og unge, red. Gudrun Kløve Juuhl m.fl., 119-144. Oslo: Cappelen Damm Akademisk.

Midt-Telemark kommune. 2019. Målbruksplan. https://midt-telemark. kommune.no/om-kommunen/styrende-dokumenter/malbruksplan/ [Lasta ned 17.06.2020]

Molde kommune. 2019. Møteprotokoll. Kommunestyret for nye Molde kommune 14.11.19. https://www.motekalender.molde.kommune.no/ ato/ephorte/285683/mteprotokoll.1045386.34193ac9d3.pdf [Lasta ned 07.05.2020]

Mållova. 1980. Lov om målbruk i offentleg teneste (LOV-1980-04-11-5). https://lovdata.no/dokument/NL/lov/1980-04-11-5 [Lasta ned 12.08.2019]

Målvedtak i kommunar og fylkeskommunar. 2007. Forskrift om målvedtak $i$ kommunar og fylkeskommunar (FOR-2007-04-01-378). https://lovdata.no/dokument/SF/forskrift/2007-04-01-378 [Lasta ned 12.08.2019]

Nordal, Anne Steinsvik. 2011. Nynorsk som hovudmål. I: Norsk $=n y$ norsk og bokmål. Ei grunnbok om nynorsk i skolen, red. Benthe Kolberg Jansson \& Synnøve Skjong, 109-135. Oslo: Det Norske Samlaget.

Nordal, Anne Steinsvik. 2017. Meir nynorsk for nynorskelevane. I: Norsk som reiskaps- og danningsfag, red. Birgitte Fondevik \& Pål Hamre, 239-257. Oslo: Det Norske Samlaget. 
Odda kommune. 2016. Intensjonsavtale for samanslåing av Odda kommune, Jondal kommune og Ullensvang herad. https://www.odda.kommune.no/Handlers/fh.ashx?MId1=282\&Filld =2399 [Lasta ned 18.06.2020]

Opplæringslova. 1998. Lov om grunnskolen og den vidaregåande opplaringa (LOV-1998-07-17-61). https://lovdata.no/dokument/NL/lov/199807-17-61 [Lasta ned 02.06.2020]

Patten, Alan \& Will Kymlicka. 2003. Introduction: Language rights and political theory: Context, issues and approaches. I: Language rights and political theory, red. Will Kymlicka \& Alan Patten, 1-51. Oxford: Oxford University Press.

Rambø, Gro-Renée. 2014. Språksosiologi og norsk språkhistorieskriving. Maal og Minne 2014 (hefte 2), 18-55.

Regjeringen. 2014. Nettsider og automater skal kunne brukes av alle. https://www.regjeringen.no/no/aktuelt/Nettsider-og-automaterskal-kunne-brukes-av-alle/id764871/ [Lasta ned 21.01.2021]

Regjeringen. 2020. Fakta om kommunereformen. https://www.regjeringen.no/no/tema/kommuner-og-regioner/kommunereform/kommunereform/id2548377/ [Lasta ned 08.02.2021]

Sandnes kommune. 2016. Prinsippdokument. Muligheter ved en ny kommune. https://www.nyesandnes.no/dokumenter/dokumenter\%20 generelt/endelig\%2oprinsippdok\%2oforsand\%20sandnes\%206\%20ju ni\%202016.pdf [Lasta ned 17.06.2020]

Solvoll, Mona Kristin, Alexander Buhmann \& Tor Bang. 2018. Vi stoler på kommunens nettsider, men er ikke fornøyd med innholdet. https://www.bi.no/forskning/business-review/articles/2018/ 02/vis-toler-pa-kommunens-nettsider-men-er-ikke-fornoyd-medinnholdet/ [Lasta ned 21.01.2021]

Språkrådet. 2019. Nye Ålesund er årets nynorskkommune. https://www. sprakradet.no/Vi-og-vart/Prisar_og_karingar/arets-nynorskkommune/ [Lasta ned 21.10.2019]

Språkrådet, Landssamanslutninga av nynorskkommunar \& Nynorsk kultursentrum. 2011. Unders $\varnothing$ king om målbruken i nynorskkommunar - rapport. https://fido.nrk.no/5911888bob71da3834bb1a93d827e7 b2e89955eaabe82b4539879548422f558f/Rapport.pdf [Lasta ned 22.01.2021] 
Stavanger kommune. 2018. Målform $i$ nye Stavanger kommune. http://opengov.cloudapp.net/Meetings/STAVANGER/Meetings/Details/692017?agendaItemId $=216061$ [Lasta ned 17.06.2020] Teigen, Håvard. 2001. Nynorsk og regional utvikling. I: Kampen for språket, red. Elisabeth Bakke \& Håvard Teigen, 140-173. Oslo: Det Norske Samlaget.

Thingnes, Jorunn Simonsen. 202O. Å velge eit minorisert språk: mellom språkpolitiske ideal og språkleg realitet. Maal og Minne 2020 (hefte 1), 127-168.

Tvitekkja, Sigfrid. 2010. Ja, nei og jau om mållova. Språknytt 2010 (hefte 2), 24-25.

Vikør, Lars S. 2011. Språkog samfunn - heime og ute. Oslo: Novus.

Vogt-komitéen. Komitéen for å vurdere språksituasjonen m.v. 1966. Innstilling om språksaken. Oslo: Kirke- og undervisningsdepartementet.

Ålesund kommune. 2019. Målvedtak for Ålesund kommune fra 1.1.2020. https://alesund.kommune.no/innsyn.aspx?response=journalpost_d etaljer\&journalpostid $=2019003008 \&$ scripturi $=/$ innsyn.aspx\&skin $=$ infolink $\&$ Mid1 $=1558 \&$ [Lasta ned 17.06.2020] 
Tom Flaten og Magnhild Vollan

\section{Vedlegg}

Vedlegg 1: Eksempel på bokmålsmal i nynorskkommune (Bjerkreim kommune).

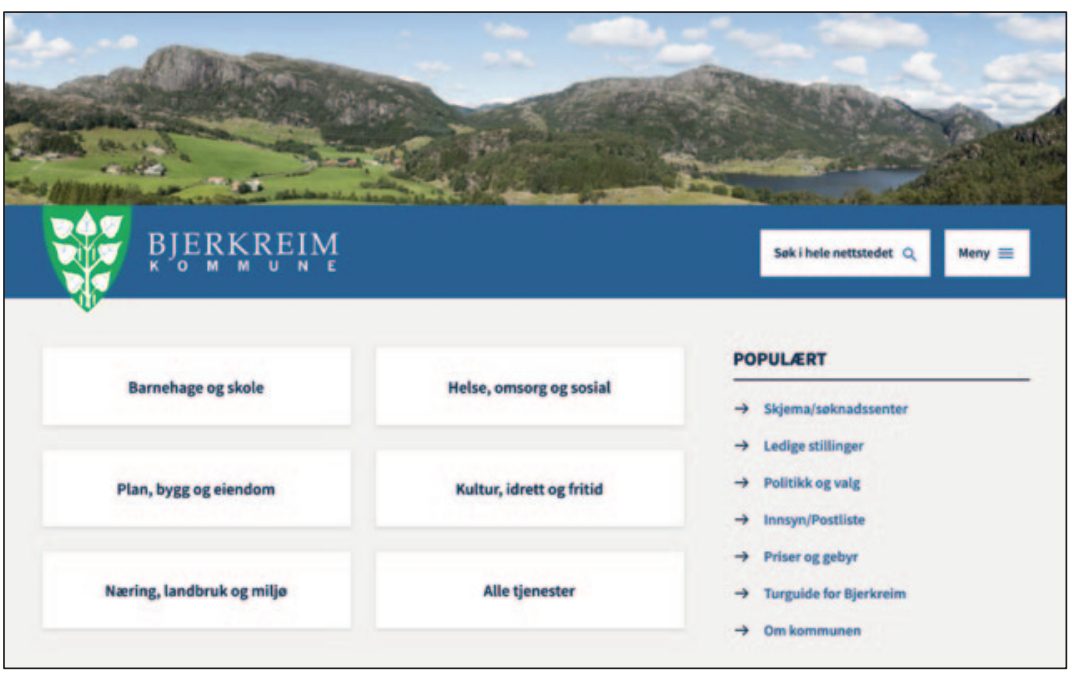

Vedlegg 2: Eksempel på nynorskmal i språklig nøytral kommune (Hå kommune).

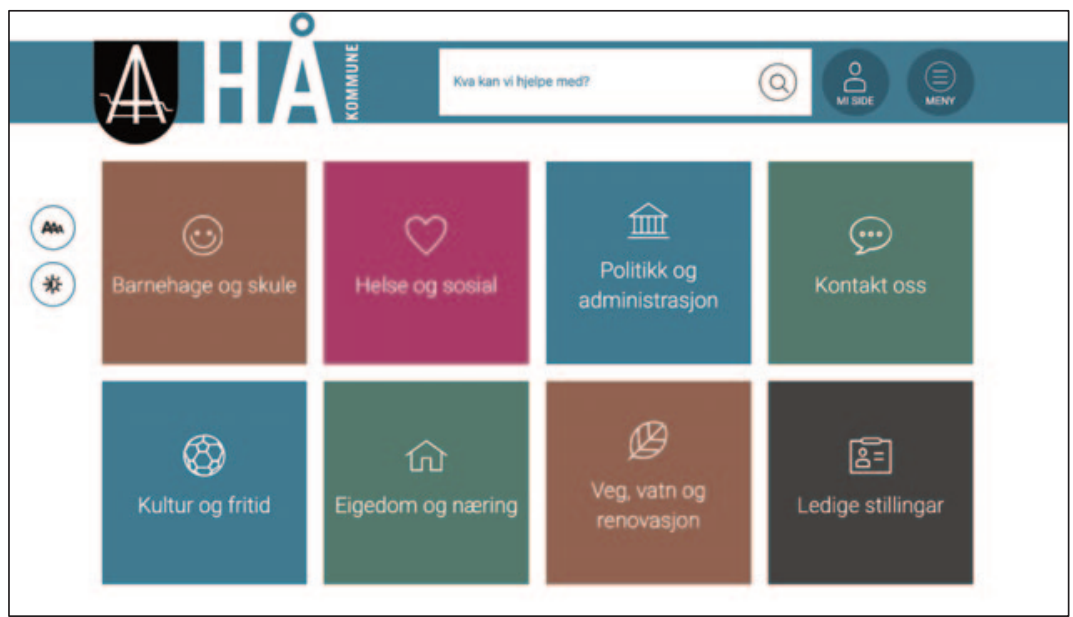


Vedlegg 3: Eksempel på blanda mal i nynorskkommune (Hjartdal kommune).

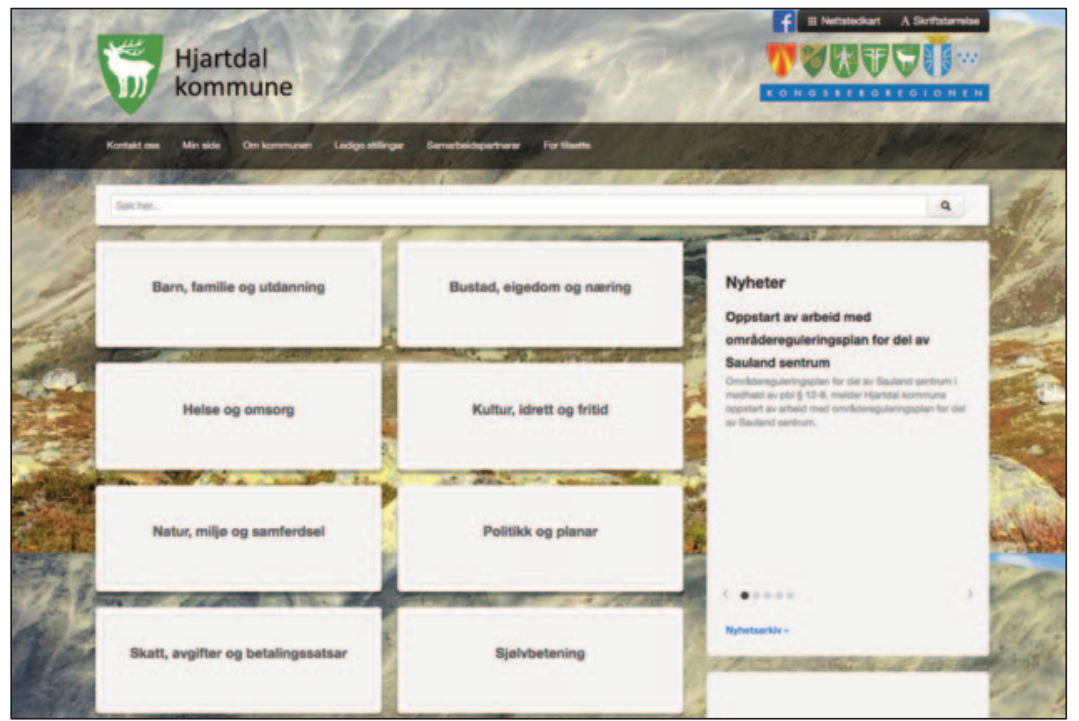

Vedlegg 4: Eksempel på nyhetssak på bokmål i nynorskkommune (Surnadal kommune).

\section{Pressemelding: innbyggerne i Møre og Romsdal fylke deltar i ny, nasjonal undersøkelse om helse og sykdom}

Fra og med lørdag 5. oktober vil tilfeldig utvalgte personer i Møre og Romsdal fylke motta en SMS hvor de blir bedt om à svare på en kort spørreundersøkelse. Det vil ta ca. 5 minutter â svare.

Norge onsker á redusere for tidlig dod av ikke-smittsomme sykdommer med 30 prosent innen 2030. Data fra en ny undersokelse vil giare at helsemyndighetene kan felge med pa utviklingen av disse sykdommene, nemlig kreft, kols, diabetes og hjerte-og karsykdommer.

- Livsstilsfaktorer som vekt, kosthold, fysisk aktivitet samt alkohol-og tobakksbruk er salkalte helseindikatorer. De kan fortelle hvordan fremtidig helse vill bli, forklarer professor inger Torhild Gram ved Nasjonalt senter for e-helseforskning. Hun leder arbeidet med den nye undersekelsen som skal foregà ved hjelp av mobilen.

- Undersokelsen aHelse og sykdoms vil gi myndighetene viktig informasjon pá en enkel máte slik at de kan sette i gang tiltak som bedrer folkehelsen, forklarer professoren.

Fra og med lerdag 5. oktober vil tilfeldig utvalgte personer i Mere og Romsdal fylke motta en SMS hvor de blir bedt om à svare pà en kort sporreundersakelse. Det vil ta ca. 5 minutter â svare.

vi háper sá mange som mulig velger à svare. Det er vấr fremtidige helse det gjelder, og alle bidrag er kjempeviktiget understreker professor Gram. 
Vedlegg 5: Eksempel på nyhetssak på nynorsk i språklig nøytral kommune (Sør-Fron kommune).

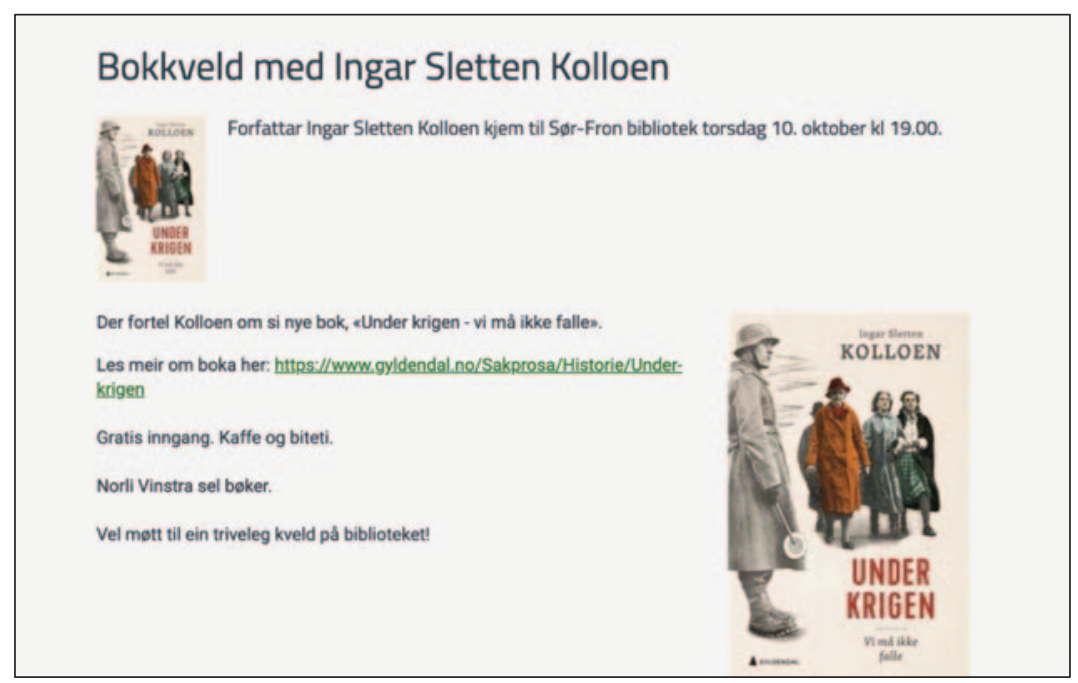

Vedlegg 6: Eksempel på nyhetssak på bokmål i språklig nøytral kommune (Karmøy kommune).

\section{Nå kan du søke om sosialhjelp digitalt i Karmøy}

Sist oppdatert 3. oktober 2019 09:05

Den nye digitale løsningen gior at du kan soke sosialbjel. bjemmefra hele døgnet $\mathrm{pà} \mathrm{pc}$, mobil eller nettbrett. For à seke digitalt, má du logge deg inn pà *Ditt NAV» pá nav.ne med Bankid eller andre sikkerhetslesninger som Buypass eller Comfides. Hvis du trenger hjelp til utfyllingen, kan du ringe NAV Kontaktsenter pả 55553333 og fả veiledning over telefon. Du kan ogsà fả hjelp pả NAV Karmøy-Bokni

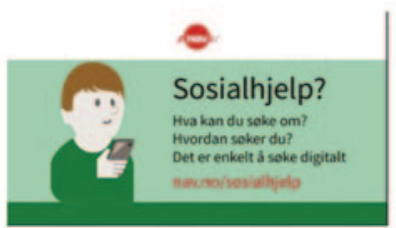
àpningstiden mellom kl 11-14.

Hvis du av ulike àrsaker ikke kan eller ønsker à benytte deg av den digitale søiknaden om sosialhjelp, kan du fortsatt møte opp pả NAV-kontoret eller bruke papirseknad.

Mer informasjon på finner du pả Veiviser akonomisk sosialbjelppå nav.no 


\begin{abstract}
This article presents an empirical study of language practices on $277 \mathrm{mu}-$ nicipalities' websites. The material consists of two parts. Part 1, which was collected in October 2019, is made up of 271 municipalities that either have decided to have Nynorsk as main language or to be linguistically neutral. Part 2 was collected in May 2020 and is made up of six newly merged municipalities consisting of previous municipalities that had different language decisions, where at least one had a decision to have $\mathrm{Ny}$ norsk. The study seeks to answer this question: To what extent is there correspondence between the municipalities' language decision and their language practice on the websites? The article shows lack of correspondence between language decisions and language practices in many municipalities and consequences of municipal mergers. A main finding is that linguistically neutral municipalities mainly use Bokmål on their websites. Based on this, we discuss language neutrality in the light of language rights theory, and what lies in the concept of linguistically neutral municipality.
\end{abstract}

Tom Flaten

Universitetet i Agder

Institutt for nordisk og mediefag

Postboks 422

NO-4604 Kristiansand tom.flaten@uia.no

Magnhild Vollan

Universitetet i Agder

Institutt for nordisk og mediefag

Postboks 422

NO-4604 Kristiansand

magnhild.vollan@uia.no 